Federal Reserve Bank of Dallas

Globalization and Monetary Policy Institute

Working Paper No. 210

http://www.dallasfed.org/assets/documents/institute/wpapers/2014/0210.pdf

\title{
The Federal Reserve Engages the World (1970-2000): An Insider's Narrative of the Transition to Managed Floating and Financial Turbulence*
}

\author{
Edwin M. Truman \\ Peterson Institute for International Economics
}

October 2014

\begin{abstract}
This paper traces the evolution of the Federal Reserve and its engagement with the global economy over the last three decades of the 20th century: 1970 to 2000. The paper examines the Federal Reserve's role in international economic and financial policy and analysis covering four areas: the emergence and taming of the great inflation, developments in US external accounts, foreign exchange analysis and activities, and external financial crises. It concludes that during this period the US central bank emerged to become the closest the world has to a global central bank.
\end{abstract}

JEL codes: F3, F31, F32, F33, F34, E4, E42, F5, F52, F53

\footnotetext{
* Edwin M. Truman, Peterson Institute for International Economics,1750 Massachusetts Avenue NW, Washington, DC 20036. 202-328-5432. ttruman@piie.com. I thank Kent Troutman for his dedicated assistance in preparing the charts for this paper. I am also indebted, without implicating them in any of the content of this paper, to Carol Bertaut, Ralph Bryant, Terrence Checki, Thomas Connors, Sam Cross, Hali Edison, Joe Gagnon, Dale Henderson, C. Randall Henning, George Henry, Peter Hooper, Nancy Jacklin, Karen Johnson, Dino Kos, Catherine Mann, Jaime Marquez, Maurice Obstfeld, Adam Posen, Larry Promisel, Jeffrey Shafer, Charles Siegman, David Stockton, Charles Thomas, Tracy P. Truman, and participants in the Federal Reserve Bank of Dallas conference "The Federal Reserve System's Role in the Global Economy” for their advice, comments, and support. The views in this paper are those of the author and do not necessarily reflect the views of the Peterson Institute for International Economics, the Federal Reserve Bank of Dallas or the Federal Reserve System.
} 


\title{
The Federal Reserve Engages the World (1970-2000): An Insider's Narrative of the Transition to Managed Floating and Financial Turbulence
}

\author{
Edwin M. Truman
}

This paper traces the evolution of the Federal Reserve and its engagement with the global economy over the last three decades of the 20th century: 1970 to 2000. The paper examines the Federal Reserve's role in international economic and financial policy and analysis covering four areas: the emergence and taming of the great inflation, developments in US external accounts, foreign exchange analysis and activities, and external financial crises. It concludes that during this period the US central bank emerged to become the closest the world has to a global central bank.

\section{JEL Codes: F3, F31, F32, F33, F34, E4, E42, F5, F52, F53}

Keywords: Federal Reserve, Federal Open Market Committee, inflation, macroeconomic policies, monetary policy, external balance, exchange rates, exchange market intervention, financial crises, third world debt crises,

Mexican crisis, Asian financial crises

Author's note: 1 thank Kent Troutman for his dedicated assistance in preparing the charts for this paper. 1 am also indebted, without implicating them in any of the content of this paper, to Carol Bertaut, Ralph Bryant, Terrence Checki, Thomas Connors, Sam Cross, Hali Edison, Joe Gagnon, Dale Henderson, C. Randall Henning, George Henry, Peter Hooper, Nancy Jacklin, Karen Johnson, Dino Kos, Catherine Mann, Jaime Marquez, Maurice Obstfeld, Adam Posen, Larry Promisel, Jeffrey Shafer, Charles Siegman, David Stockton, Charles Thomas, Tracy P. Truman, and participants in the Federal Reserve Bank of Dallas conference “The Federal Reserve System's Role in the Global Economy” for their advice, comments, and support.

The Federal Reserve enters its second century as the closest the world has to a global central bank. The US central bank is more influential and engaged globally than at any previous time in its history and more than any other central bank.

In formulating US monetary policy, the Federal Reserve increasingly has to take account of the developments outside of the US economy and the impacts of its policy decisions on other economies and global financial markets. These trends intensified in the 21st century, but they emerged in the last three decades of the 20th century, the focus in this paper.' 1 review four areas of the Federal Reserve's role in the global economy: (1) the emergence and taming of the great inflation; (2) developments in US external accounts; (3) the foreign

\footnotetext{
${ }^{1}$. The decades, for my purposes, end in 1980, 1990, and 2000. Other conference papers address earlier and more recent periods.
} 
exchange value of the US dollar, US exchange rate policy, and international financial markets; and (4) external financial crises. These interrelated areas absorbed the majority of Federal Reserve activity on international economic and financial policy issues in this period.

On the great inflation, the intellectual and policy challenge facing the Federal Reserve in the 1970s was not only to recognize the inflation problem but also to diagnose the phenomenon not as something imported from abroad via increases in energy prices and exogenous dollar depreciation, but primarily as homegrown, nurtured if not propagated primarily by Federal Reserve policy.

Prospects for the US trade and current account balances and the asymmetrical global adjustment process were a principal policy preoccupation in the wake of the disintegration of the Bretton Woods system of fixed exchange rates. That policy focus persisted into the 1980s. By 2000, trends in the US external accounts and the sustainability of the US international investment position had largely receded as a pressing policy concern of the Federal Reserve, but were about to reemerge.

The foreign exchange value of the US dollar is central to the analysis of prospects for the US external accounts, but has many other dimensions. For the Federal Reserve, the most controversial dimension was the involvement of the Federal Reserve System (System) in US foreign currency operations. By the mid-1990s, this issue had become less salient because the tool of foreign exchange market intervention fell into disuse.

Throughout the last third of the 20th century, the Federal Reserve was deeply engaged in the management and prevention of external financial crises of a growing list of countries of importance. This conditioned its emerging global role.

\section{THE SETTING}

Contrary to the common narrative, the collapse of the Bretton Woods exchange rate system in the early 1970s did not free the Federal Reserve to focus exclusively on the domestic economy largely because the US economy was becoming increasingly globally integrated. The United States and its central bank became enmeshed in global economic and financial developments to a much greater degree than under the Bretton Woods system.

In 1970 US exports of goods and services-one measure of the influence of economic activity in the rest of the world on the US economy-were 5 percent of US GDP. By 2000, they were almost 10 percent. Importsa measure of the economic influence of the United States on the rest of the world-rose from 5 percent of GDP in 1970 to 14 percent, by 2000; see figure $1^{2}$

The increasing integration of the United States with the global financial system was even more dramatic. US foreign assets at the end of 2000 were $\$ 6.2$ trillion, or 60 percent of US nominal GDP, compared with a

\footnotetext{
${ }^{2}$. Figure 1 and some of the other figures present data after 2000 in the shaded area to emphasize the continuation of these trends.
} 
mere 20 percent in 1970. On the other side of the ledger, foreign assets in the United States in 2000 were $\$ 7.6$ trillion (72 percent of nominal GDP), up from a mere $\$ 120$ billion in 1970 (only 11 percent of nominal GDP); see figure 2 .

An examination of transactions data reinforces this picture of growing US global financial involvement. In the first five months of 1977, the earliest available data, foreign purchases and sales of long-term domestic and foreign securities averaged $\$ 105$ billion at an annual rate of 5 percent of US nominal GDP in the first quarter of that year. By 2000, purchases and sales averaged $\$ 23.3$ trillion at an annual rate of 232 percent of US nominal GDP. $^{3}$

The Federal Reserve policies and activities were strongly affected by these trends, and vice versa. Research demonstrates that US economic and financial developments create the largest spillovers to other countries and regions (Bayoumi and Bui 2010, 2012; Bayoumi and Swiston 2007). The main source of these spillovers is financial conditions, which are heavily influenced by Federal Reserve policies. Smaller US domestic shocks in the period 1988 to 2006 compared with 1970 to 1987 were central to the global moderation in output fluctuations in the second period, but the US and global financial environment was about to become dramatically more volatile. Tamim Bayoumi and Andrew Swiston $(2007,15)$ conclude that their results support "the view that more stable US monetary policy was crucial for stabilizing real and financial uncertainty at the center of the system, allowing all countries to enjoy a less volatile environment."

Federal Reserve officials were uncomfortable being thrust deeply into international economic and financial developments. The Federal Reserve's monetary policy mandate covers only domestic objectives. ${ }^{4}$ For some, the international activities and considerations that involved the Federal Reserve in the last third of the 20th century were an irritant, at best, or a dangerous distraction, at worst. Some saw Federal Reserve involvement with other central banks and countries as potentially compromising Federal Reserve independence from US domestic political forces. The reason was that Federal Reserve involvement in international economic and financial issues generally required the Federal Reserve to cooperate with the US executive branch, in general, and with the Treasury, in particular.

By 2014 the comparable figures were $\$ 74.3$ trillion and 467 percent. Sources for these data are the US Treasury, http://www.treasury.gov/ticdata/Publish/sl_99996.txt (accessed on August 8, 2014), and the US Department of Commerce, http://bea.gov/national/index.htm\#gdp (accessed on August 8, 2014).

: The Federal Reserve's monetary policy objectives to "maintain long run growth of the monetary and credit aggregates commensurate with the economy's long run potential to increase production, so as to promote effectively the goals of maximum employment, stable prices, and moderate long-term interest rates, which are specified in section $2 \mathrm{~A}$ of the Federal Reserve Act (Board of Governors of the Federal Reserve System), do not recognize the openness of the US economy. However, section 2B (b) of the act, prescribing the content of semiannual reports to the Congress on monetary policy, explicitly requires "a discussion of the conduct of monetary policy and economic developments and prospects for the future, taking into account past and prospective developments in employment, unemployment, production, investment, real income, productivity, exchange rates, international trade and payments, and prices [emphasis added by author]." 
My purpose in this paper is not to resolve questions of motivation of monetary policy decisions during this period (e.g., Bordo and Eichengreen 2013a, Cooper and Little 2000, Eichengreen 2013, and Meltzer 2013). Federal Reserve chairs, governors, and Reserve Bank presidents often use multiple arguments to support their policy preferences in meetings of the Federal Open Market Committee (FOMC, or Committee) and other discussions of policy. Thus, it is quixotic to try to establish the evolution of the relative weight of international considerations in Federal Reserve policies, including policies other than monetary policy narrowly defined. My aim is to demonstrate that between 1970 and 2000, despite the reluctance of many in the Federal Reserve, monetary policy and other activities unavoidably became embedded in an increasingly globalized economic and financial system.

1 review the evolution of Federal Reserve analyses of, as well as involvement in, the four areas listed earlier. 1 treat each decade in turn. Because the areas are intertwined, 1 vary the order in which 1 treat them in each decade. $^{5}$ In the process, 1 do identify 18 instances in which either developments in the global economy or policies of other countries substantially affected Federal Reserve decision making or activities (type A); Federal Reserve decisions were undertaken primarily to support other countries but with commensurate benefits for the United States (type B); or occasions of decisions in win-win cooperation (type C).

As background, 1 reviewed the titles and, where available, the abstracts, summaries, and content of 695 International Finance Discussion Papers (IFDPs) released between August 1971 and December 2000. These papers illustrate the depth and range of issues on which the staff worked during the 30 years covered by this paper not only at the Board but by logical extension throughout the System. ${ }^{6}$ In many cases, the papers were based on work that had been previously or was subsequently presented to the Board or Federal Open Market Committee (FOMC). Interestingly, the number of IDPSs was 75 percent more in the 1990s than in the 1970s, even though the staffing level in the Division of International Finance (IF) was essentially unchanged over this 30-year period at between 100 and 110 people.

\section{THE 1970S: MONETARY FREEDOM AND THE BATTLE AGAINST INFLATION}

Alan Meltzer $(2009,843)$ writes, “The years 1973 to 1979 were the least successful period for postwar Federal Reserve policy." Few observers disagree with his bottom line even if many, as 1, reject his view that the principal cause of the Federal Reserve's failure was that, starting in the mid-1960s, it cooperated too extensively with the executive branch.

: The three decades cover most of the period in which 1 was at the Board of Governors as an economist starting in 1972, as director of the Division of International Finance starting in 1977, and as a collaborator while 1 was at the Treasury from late 1998 until early 2001. (Hence, 1 often write we.) For a more personal view of the same period, see Truman (2014).

: Although many papers touch on more than one area, 1 classify them under only one of the four areas that 1 cover in this paper plus three additional headings: large-scale econometric modeling, foreign economies other than economies in crisis, and a diverse "other" group of papers. 
The 1970s was a turbulent decade. The Bretton Woods exchange rate system collapsed amid associated concerns about the US external accounts. Gyrations in exchange rates and exchange rate arrangements were poorly understood and analyzed. Increases in energy prices along with mistakes in macroeconomic policies contributed to global recession, rising inflation, and external financial crises. The Federal Reserve finally addressed the US inflation crisis in October 1979.

\section{The International Monetary System and US External Accounts}

In August 1971 the link between the dollar and the official price of gold was suspended, which turned out to be permanent. The Bretton Woods system began its final unraveling. Contrary to some expectations at the time, its did not liberate Federal Reserve monetary policy or the Federal Reserve from concerns about the US external accounts; see Bryant (2014) and Solomon (1977 and 2014). ${ }^{7}$

From 1960 to 1970 the United States had a current account surplus, but the surplus was not large enough to cover net private capital outflows. The result was official settlements deficits in the form of reductions in reserves of gold and other assets and increases in foreign official claims on the United States. The Nixon administration sought a negotiated devaluation of the US dollar against other currencies to achieve a US current account surplus of sufficient size that the combination of the current account surplus and net private capital outflows, which were taken as a given, would not lead to a significant further buildup of foreign official claims on the United States.

In the 1970s US external adjustment continued to preoccupy the staff and to a lesser extent the FOMC. In 1970 US exports and imports of goods and services were only 5 percent of GDP. Fluctuations in net exports in the 1960s and early 1970s hardly mattered for the projected path of economic activity and employment (Cooper and Little 2000, figure 2). By 1980 this was no longer true.

Robert Solomon $(1977,209)$ reports that the Board staff calculated that the Smithsonian agreement had resulted in a nominal devaluation of the dollar of between 6.5 and 7.75 percent, depending on the weights chosen. Under the methodology now used by the Board staff, the depreciation was 5.5 percent in real, or priceadjusted, terms between July 1971 and January 1972; see figure 3. The question was whether the devaluation was large enough to achieve sufficient adjustment in the US current account balance. The initial objective had been an improvement of $\$ 13$ billion, about 0.3 percent of GDP. After the Smithsonian agreement, the staff calculated that the total improvement would be only $\$ 8$ billion (Solomon 1977, 210). But it was slow in coming. The staff

\footnotetext{
7. Chairman Arthur Burns chose Ralph Bryant in 1972 to succeed Robert Solomon as the IF division director to address new and continuing policy challenges. Bryant and his colleagues hired additional staff, expanding the total size of the division by about a third. Bryant also initiated a project to construct a multicountry model (MCM) to analyze global economic and financial developments. The project, unique at the time, resulted in a large number of papers and ultimately a book (Stevens et al. 1984). Many of the papers were released in 1976. See Berner et al. (1975 and 1977) for initial results. See Brayton et al. (1997) for an account of the evolution of macro models at the Federal Reserve Board and how the MCM fit into that history.
} 
forecast in January 1972, immediately after the Smithsonian agreement, was for an improvement of $\$ 1$ billion in that year.

As the year progressed, the forecast turned into a projected deterioration of $\$ 5$ billion. This forced the staff to analyze the effects of the dollar's devaluation that resulted from the Smithsonian agreement and how much adjustment was left in the pipeline. In early 1973 the staff made a major presentation to the Board of its results, concluding that the adjustment would fall short of what was needed (e.g., Junz 1973 and Clark 1974).

Shortly thereafter, Treasury Secretary George Shultz sent Undersecretary Paul A. Volcker around the world to negotiate a second devaluation of the dollar on February 12, 1973. But by early March, the new fixed exchange rates had become unstuck, and—something that would be inconceivable today-foreign exchange markets in Europe and Japan were closed for two days. In mid-March, the exchange rate system lurched into generalized managed floating to the delight of many economists and dismay of many other observers.

The dollar continued to decline. It was enough to bring the cumulative real effective depreciation of the dollar from January 1970 to July of 1973 to 20 percent. $^{8}$ Consequently in the December 1973 Greenbook report on current economic and financial conditions (FRB 1973), nominal net exports were projected to improve by $\$ 9.4$ billion in 1973 and to increase a further $\$ 6.4$ billion in 1974. In part due to the oil embargo imposed during the Arab-lsraeli war in October 1973 and the subsequent quadrupling of the oil price, the 1974 forecast did not materialize.

The FOMC initially reacted to the oil price shock by continuing to ease monetary policy, indexed by the federal funds rate, starting at the September 1973 meeting (type A impact). The aim was to counter the effects of higher oil prices on US real economic activity. The easing continued until March 1974. The Committee then began to take into consideration that increases in oil prices also contributed to inflation and that it was unwise to ratify those increases via lower short-term real interest rates; see figure 4 .

The dollar's depreciation and the increase in global oil and other commodity prices spawned a cottage industry in estimating rules of thumb of the effects of such shocks on inflation in which IF staff participated (Katz 1973, Kwack 1973, Berner et al. 1974, and Hooper and Lowery 1979). In IF, we were uncomfortable that our rules of thumb, which we used in forecasting, contributed to the opinion that inflation was merely caused by rising prices with little the central bank can do about it.

\section{Exchange Rates: Analysis and Operations}

Policy and analysis of exchange rates involved more than just measuring effects on the price level and inflation. It involved five interrelated dimensions: measurement, exchange rate determination, US intervention operations, effectiveness of such operations, and the Federal Reserve's role in them.

\footnotetext{
${ }^{8}$. Here and below, except where otherwise noted, I cite the change in the foreign exchange value of the dollar in nominal or real (price-adjusted) terms using the methodology that the staff of the Federal Reserve Board uses today: see footnote 9.
} 
On measurement, one issue was the relevant exchange rate for the US dollar. Financial market participants, and our colleagues at the Federal Reserve Bank of New York, tended to think of the exchange rate for the US dollar vis-à-vis at most four other currencies: the German mark, the Swiss franc, the Japanese yen, and the British pound (and most frequently just the deutsche mark). At the Board, we tended to think about exchange rates as macroeconomic variables rather than financial variables and-recognizing that no single country or currency dominated US economic or financial transaction-preferred not to focus on one bilateral exchange rate. Following the move to generalized floating in 1973, we adopted a measure of the dollar's foreign exchange value in terms of the currencies of the other Group of Ten (G-10) countries. ${ }^{9}$

A second measurement issue was the definition of exchange market intervention (Adams and Henderson 1983). Here analysis and reporting was constrained by the availability of data shared by other countries with the Open Market Desk at the Federal Reserve Bank of New York (Desk), and the conventions associated with the foreign currency operations of other monetary authorities. The principal distinction was between intervention in the open market and off-market transactions with customers, which some people did not regard as intervention. Another related to intervention in the forward rather than the spot market.

Once nominal exchange rates became detached from parities, the challenge was how to think about exchange rate determination. Richard Meese and Kenneth Rogoff (1981, 1982, and 1983) produced the seminal contribution, concluding that, except in the long run, existing models of exchange rate determination were of limited use out of sample. This work was inspired by the need to provide forecasts for the Federal Reserve Board and FOMC and by questions from members. ${ }^{10}$

Turning to US foreign exchange operations, they are conducted by the Desk on behalf of the FOMC and/or the Exchange Stabilization Fund of the US Treasury. Under Bretton Woods, and until August 1971, US

9. In addition to Germany, Japan, Switzerland, and the United Kingdom, these were Belgium, Canada, France, Italy, the Netherlands, and Sweden, making a total of 11, including the United States. A considerable amount of research went into the question of whether we should use different weights for different purposes, but in the end it was decided that little was gained from differentiation. See Mico Loretan (2005) for a report on the index used in this paper, which is now more sophisticated and covers the currencies of 26 countries or currency areas, and historically 10 of the 15 countries now included within the euro area. Earlier reports and analyses include Leahy (1998), Pauls (1987), and Hooper and Morton (1978a and 1978b).

${ }^{10}$. The Meese-Rogoff analysis builds on earlier investigations of exchange rates and exchange rate determination. Michael P. Dooley and Jeffrey R. Shafer (1976) find that foreign exchange markets do not satisfy weak tests of efficiency. Peter Isard (1977) presents an early survey of the literature on exchange rate determination. (This paper later appeared in 1978 in Princeton Studies in International Finance 42 with the title "Exchange-Rate Determination: A Survey of Popular Views and Recent Models.”) Peter Hooper and John Morton (1980) produce their own model of exchange rate determination. It combines the monetary approach explaining movements in equilibrium relative price levels with the portfolio balance approach involving supplies and demands for assets that are imperfect substitutes; they use as a proxy for the latter the US cumulative current account balance. Hali Edison's evaluation and briefing (1988a and 1988b, respectively) examine the staff's exchange rates forecasting record from 1979 to 1987 and find that it slightly outperformed the random walk model as well as the HooperMorton model. 
operations were almost entirely conducted for the System's account but were limited in size and scope. Many of those operations consisted of drawing foreign currencies on reciprocal currency (swap) arrangements to buy dollars purchased by other central banks to provide cover and/or to protect the US gold stock with the hope of buying the foreign currency in the market before the swap matured and the foreign currency had to be repaid." Foreign exchange operations were conducted for multiple purposes under an authorization and directive of the FOMC that were revised or reaffirmed at least once a year. ${ }^{12}$

After the closing of the gold window, the United States refrained from operating in the foreign exchange market until July 19, 1972. Once resumed, operations continued until the dollar was devalued for a second time on March 12, 1973. Once again, US authorities withdrew from the market. That withdrawal lasted only until July 10 when, under heavy pressure from partner countries with concerns about a de facto third devaluation of the dollar, the Federal Reserve resumed operations.

\section{Global Recession and Financial Turmoil}

With inflation increasingly becoming a pressing issue, the FOMC pushed up the federal funds rate from March to July 1974. The Committee then responded to the recession that had started in November 1973 by reducing the rate. Fueled by the change in the global monetary regime, increases in petroleum prices, and inconsistent if not incoherent policy responses to both in the early 1970s, the recession was not confined to the United States. Global growth averaged about 5.5 percent in 1972 and 1973, and slumped to 2.2 percent in 1974 and 1.2 percent in $1975 .^{13}$

The increases in oil prices and global economic and financial turmoil were associated with external financial crises in both advanced and developing countries. The Federal Reserve was drawn into several of them, increasing the size of swap lines with the central banks of Italy, Mexico, and the United Kingdom and allowing them to be drawn upon (type B impact). ${ }^{14}$

\footnotetext{
". A foreign currency swap involves the simultaneous purchase (sale) of a currency for another accompanied by a commitment to reverse the transaction in the future, which is normally 90 days.
}

". See, for example, FRB (1971, 9-15) for the authorization and directive in effect when President Nixon closed the US gold window in 1971. It states that the purposes of system operations in foreign currency are to safeguard the value of the dollar, make international payments more effective, further monetary cooperation, insure that exchange rate movements (within IMF limits) reflected underlying economic forces, and promote growth in international liquidity in accordance with the needs of the world economy.

\footnotetext{
13. These data are GDP volume measures from the International Monetary Fund's International Financial Statistics Yearbook for 1999.
}

". The United Kingdom had the additional challenge of managing the continued unwinding of the reserve role of sterling, and the Federal Reserve agreed to help backstop that process (Schenk 2010). Raymond Lubitz (1978) wrote about the ltalian economic crises of the 1970s long before they were over. 
In all three of these financial crises, drawings on swap lines with the Federal Reserve were explicitly or implicitly linked to the establishment of IMF-supported economic stabilization and reform programs. In the case of the United Kingdom, Arthur Burns wrote to the British authorities explicitly linking its swap drawing in 1976 to a commitment to go to the IMF if the Bank of England could not repay the drawing within six months.

Burns took an intense interest in the external financial crises of the mid-1970s and their impact on the international financial system. One of his last major speeches as chairman (Burns 1985) was titled "Need for Order in International Finance." He advocated a stronger role for the IMF in surveillance, better information about international lending from both borrowers and lenders, avoidance of persistent payments deficits and surpluses, and energy conservation.

In this period, IF staff members started to produce semiannual papers for the Board on economic and financial trouble spots around the world. They contained assessments of countries likely to have external financing problems or were already experiencing such problems. These "strictly confidential" reports were sent to the Board but not to the full FOMC. They did inform other presentations to the Committee.

In 1979 the Federal Reserve, Office of the Comptroller of the Currency (OCC), Federal Deposit Insurance Corporation (FDIC), and several state banking agencies established the Interagency Country Exposure Review Committee (ICERC) to evaluate US banks' foreign exposures and transfer risks in a consistent manner across agencies (FRB 1999b). This was not a high-profile activity except at times of international financial stress, but it meant the staff was constantly involved in such issues.

\section{International Monetary System Reform and Federal Reserve Foreign Exchange Policy}

Following the Smithsonian agreement, reform of the international monetary system was completed in stages. The Committee of Twenty (C-20), established in 1972 to reform the Bretton Woods system, released its Outline of Reform in June 1974. It sketched out a possible course of evolutionary reform, but was not a full blueprint for replacing the Bretton Woods system, except it preserved the central role for the IMF. In August 1975 the matter of the treatment of gold was resolved, principally between the United States and France. Historically, France had an interest in the topic, and the United States wanted to banish gold from the international monetary system. In November 1975 the issue of exchange rate arrangements was settled. This topic also principally involved the differing philosophic positions of the US Treasury, by then firmly in the camp of supporters of floating exchange rates, and the French authorities. The agreement, which was later transformed into the revised Article IV of the IMF Articles of Agreement, was embraced at the first Group of Six (G-6) Economic Summit at Rambouillet, France. $^{15}$

\footnotetext{
${ }^{15}$. The G-6 countries were the G-5 countries (France, Germany, Japan, the United Kingdom, and the United States) plus Italy; membership did not include Canada (added at the 1976 summit in San Juan, Puerto Rico, to create the G-7). The G-5 first met in Washington in March 1973 at the White House and included only finance ministers. When Burns learned this, he demanded that in the future central bank governors be included as well (which they were, along with finance ministry deputies, but normally not central bank deputies). In the late 1990s the G-7 central bank deputies began to meet separately.
} 
Once the revised Article IV had been agreed to, but before it technically became effective in April 1978, the Federal Reserve, with Henry Wallich taking the lead, undertook to reflect the agreement in revisions of the FOMC's Foreign Currency Authorization and Directive (FRB 1976a). Wallich and Treasury Undersecretary Edwin $\mathrm{H}$. Yeo painstakingly negotiated this language in six meetings lasting more than 10 hours (FRB 1976b, 12). The new directive used only one sentence to state the purpose of Federal Reserve foreign currency operations: "System operations in foreign currencies shall generally be directed at countering disorderly market conditions, provided that market exchange rates for the U.S. dollar reflect actions and behavior consistent with the proposed IMF Article IV, Section I."

Wallich was sent back to discuss with Yeo the FOMC's discomfort with initial language stating that the Desk should conduct its operations in "collaboration" with the US Treasury, on grounds that "collaboration" implied a sacrifice of Federal Reserve independence. The word in was replaced by six words: "close and continuous consultation and cooperation."

The FOMC in 1976 added a new foreign currency instrument: a set of procedural instructions governing decision making on Federal Reserve foreign exchange operations. Burns intended the procedural instructions, in part, to limit the discretion of the Desk in conducting foreign exchange operations for the System. They required the manager of the System's open market account to clear with the foreign currency subcommittee of the FOMC and for the subcommittee to clear with the full FOMC swap drawings of any or a certain size and to approve changes in the System's "overall open position" in foreign currencies beyond certain limits for intermeeting periods as well as in any day. ${ }^{16}$

\section{The US Inflation Crisis}

Through much of the second half of the 1970s, US authorities struggled with slow growth, rising inflation, a weak foreign exchange value of the dollar, and the reemergence of the US current account deficit. All this was in the context of a global economic and financial system that was at best untested and some would say lacked any structure (Truman 2012).

Starting again in July 1973, the Federal Reserve had been periodically active in both buying and selling dollars (Greene 1984a). However, with the deteriorating US current account position, and the prevailing view in the market that the US authorities were practicing benign neglect of the dollar (wanting a lower dollar and actively talking down the dollar), the dollar was under downward pressure.

\footnotetext{
16. The foreign currency subcommittee consisted of the chairman and vice chairman of the committee, the vice chairman of the Board of Governors, and one other member of the Board. A limit on the size of the System's “overall-open position” was introduced into the foreign currency authorization. It was defined as the "sum (disregarding signs) of open positions in each currency.” The open position in each currency (later changed to the net position) was defined as the spot position plus forward position with due regard for sign. In addition to the formal limit on the overall open position, there were informal understandings about foreign currency holdings in total and currency-by-currency.
} 
The pressure on the dollar intensified in 1978 (Greene 1984c). Partly as a consequence, and demonstrating their own fear of floating, Europeans created a mutual protection scheme in the form of the European Monetary System and a mechanism of fixed rates within preestablished limits. The Federal Reserve was increasingly behind the curve. The funds rate and interest rate on 10-year treasury securities were negative in real terms, had been for some time, and continued to decline (figure 4). ${ }^{17}$ The overall message from foreign policymakers and the markets was that US inflation had gotten out of hand, US monetary policy was too easy, and the US dollar was fast losing its remaining luster (Truman 2006, 174-81).

At the Bonn economic summit in June 1978, as part of a bargain aimed at stimulating the world economy and reducing the US current account deficit, the US administration pledged to reduce inflation via a voluntary program to decelerate wages and prices, promote a tighter fiscal policy, and deregulate domestic petroleum prices. The program of budget restraint and voluntary wage and price guidelines released in mid-October was a disappointment to the market, as Chairman G. William Miller had anticipated and had warned his Federal Reserve Board colleagues.

To deal with this situation, Miller helped craft the November 1, 1978, dollar rescue package in cooperation with the US Treasury. He convinced the Treasury that it could issue foreign currency-denominated US government debt in the market (Carter bonds), putting the US Treasury's money where its mouth was. The Federal Reserve agreed to a supplemental reserve requirement on large time deposits and to a 1 percentage point boost in the discount rate to a historic high of 9.5 percent, with the federal funds rate quickly following. ${ }^{18}$ The last element was to meet a condition imposed by the Bundesbank for its participation in the package. On the whole, this was a dramatic demonstration of external discipline from market and official sources that affected Federal Reserve policies on a scale not witnessed during the Bretton Woods era (type A impact); see Greene (1984b) and Truman (2004 and 2006) for more details.

However, it was not enough to arrest US inflation, and real interest rates continued to be deeply negative (figure 4). After a brief recovery, the dollar resumed its decline and US inflation continued to rise. The stage was set for the FOMC on October 6, 1979, to adopt the new operating procedures. They aimed better to control the monetary aggregates by focusing on the supply of nonborrowed reserves to the market and by tolerating a higher level of and greater movements in the federal funds rate.

". From the end of 1974 through September 1979, the real federal funds rate had been positive in only eight of 57 months. Figures 4 , 5 , and 7 use the headline consumer price index (CPI) over the previous 12 months. The real federal funds rate uses the $12-\mathrm{month}$ leading $\mathrm{CPI}$ inflation rate, and the real 10-year treasury rate uses the 36-month centered average of 12-month CPI inflation rates. These were the conventions we used in IF during most of this period.

${ }^{18}$. Chairman Miller convinced the Treasury that it could absorb any exchange risk in the general account as a cost of issuing debt rather than potentially draining the account of the exchange stabilization fund. Other elements of the package included a doubling of FOMC swap lines with the Bundesbank, Bank of Japan, and Swiss National Bank; drawing intervention resources from the IMF; and stepping up US gold sales that had been underway. 
At the MF annual meeting in Belgrade, Yugoslavia, former Chairman Burns delivered the Per Jacobsson lecture. His title was "The Anguish of Central Banking." His theme was that the Federal Reserve could not conquer inflation alone: lt needed changes in fiscal, regulatory, and tax policies in addition to explicit endorsement of restrictive policies by the central bank.

Paul Volcker arrived at the lecture late, sat on the floor, skimmed the text, and tossed it onto the floor saying, "I have it all wrong." I understood his remark because 1 knew about the proposed new operating procedures, which were the basis for his reaction. More important, Volcker en route to Belgrade had obtained a commitment from the Treasury and Council of Economic Advisors not to object to the proposed approach. Both the administration and the FOMC had become convinced that everything else had been tried and had failed to reduce US inflation. In retrospect, it was necessary to have tried and failed many other approaches before policymakers, including within the Federal Reserve, agreed that the US inflation problem was principally homegrown and could be addressed only through monetary policy (type A impact) (Truman 2005).

Experience with the new operating procedures was not smooth, in part, because of the imposition of credit controls in March 1980. The procedures also generated technical and policy controversy inside and outside the Federal Reserve. In response to those criticisms, in late 1980 and early 1981 the staff of the System, under the direction of Stephen Axilrod, undertook a comprehensive review of the experience to date (FRB 1981). The study consisted of 12 papers. Two dealt with international aspects. One by Margaret Greene offered views of the new approach from the foreign exchange trading desk. A second paper that my colleagues and 1 in IF drafted considered, in part, exchange market developments, foreign experience, and effects on US international capital flows (Truman 1981).

Two aspects of the study are noteworthy. First, it was a cooperative effort: exemplifying the Federal Reserve System at its best. Second, it helped to convince Volcker that the academic quality economic research conducted at the Board was useful to him and his leadership of the Federal Reserve.

In 1980 the Federal Reserve devoted substantial attention to the implementation of the new operating procedures, but not to the exclusion of global concerns. At the February 1980 FOMC, Jeff Shafer, George Henry, and 1 made a special presentation on international financial trends (FRB 1980).

Shafer reviewed trends in the dollar under floating and explanations for those trends. He presented data on reserve diversification and patterns of intervention by the G-10 countries. Henry reviewed developments in oil markets and their implications for global imbalances. He flagged the growing deficits of the non-oil developing countries, their increasing reliance of foreign banks to finance those deficits, and the availability of other resources in the event that they experienced external financing difficulties. In my concluding remarks, 1 said:

Thus, there are risks, and they have increased significantly in recent months with the further rise in oil prices on top of an expected slowdown in global economic activity. . . . Disruptions in the international financial system would almost certainly spill over into exchange markets, although the implications for the foreign exchange value of the dollar might be either positive or negative. Perhaps more importantly, 
many such disruptions would have serious, adverse implications for inflation, for the health of the U.S. banking system, and for prospects for economic growth in the near and long term.

With respect to the health of the US banking system and the potential external financial problems of nonoil developing countries, Volcker (1980) delivered a speech on March 1, 1980, at New York University on recycling the oil exporters' surpluses. The speech drew on a Board briefing by Henry Terrell. Volcker was so preoccupied with the credit control program that he spent less time on that speech than any other speech or testimony in my experience with him at the Board. However, the next to last paragraph was pure Volcker:

Though we have been concerned with the financial integrity of U.S. banks in urging them to be prudent in their foreign lending, we also believe such a posture is consistent with the long-run best interests of the borrowers. 1 believe we could live with the recycling situation as it is today for a period of time, though it would be foolish not to expect some hard cases to emerge. But 1 also believe that our capacity to deal with this problem as time passes could increasingly be stretched close to the limit. In that light, borrowing countries should lose no time in developing policies to maintain their credit worthiness. And it seems to me lenders and borrowers alike - that is the great bulk of the world-have the strongest kind of self-interest in actions to avoid appreciable further increases in oil prices at a time when adjustment and financing capabilities already will be increasingly stretched.

In light of subsequent developments, it is too facile to say that Volcker had warned the world of the coming global debt crisis. However, it equally would be too facile to say that the Federal Reserve was not aware of the potential risks.

\section{THE 1980S: SOVEREIGN DEBT, EXTERNAL DEFICITS, AND EXCHANGE RATES}

The Federal Reserve's successful attack on inflation had dramatic, negative repercussions on the global economy. One manifestation was the third world debt crises that dominated the 1980s. In addition, the US dollar soared and the US current account balance tanked. The abrupt U-turns in US foreign exchange policy prompted deep concerns about the Federal Reserve's role in such operations.

\section{International Concerns Contribute to Federal Reserve Easing}

The imposition of credit controls in the United States in March 1980 exacerbated the recession already under way. The lifting of those controls produced a 12-month expansion through July 1981, but the recession resumed and continued until November 1982. The federal funds rate began to decline in May 1982 for these and other reasons: The new operating procedures permitted the decline; the FOMC, Congress, and the country were becoming restless about the continuing recession; and the Committee began to pay more attention to the level of the federal funds rate. At the FOMC meeting on October 5, Axilrod (FRB 1982) told the Committee that the behavior of the monetary aggregates, which were above the targets for the year, and the behavior of the real economy were out of sync. 
The day before the November 16, 1982, FOMC meeting Volcker asked me to make a special presentation to the FOMC. He wanted me to address the risks to the US economy from the global economy, which was in its third year of recession. ${ }^{19}$ He told me that 1 did not have to hold back. 1 concluded:

In the best of circumstances, significant real and financial adjustments will be required by all. On the real side, we have roughly calculated that the external component of the expected adjustment by developing countries next year will reduce U.S. exports by at least five percent and lower U.S. real GNP by about $1 / 3$ of a percentage point. These impacts could easily be larger. The financial implications are more difficult to quantify. But the real and financial risks could be significant especially if we have underestimated the negative real interactions among countries or miscalculated the capacity of the international financial system to bridge over recent and potential disturbances. (Truman 1982, 5)

Our estimate was that net exports would subtract 0.7 percent from US real GDP from the second quarter of 1982 to the second quarter of 1983, with all the negative action from lower real exports. The decline in exports turned out to be about 50 percent larger, as the current account balance moved further into deficit. ${ }^{20}$

The Federal Reserve monetary policy responded to international influences during this period as they were impacting the US economy but also to how Federal Reserve policy was impacting the global economy (type B impact). The FOMC allowed the funds rate to decline until February 1983. By the end of 1982, the 12-month rate of inflation was 4.0 percent, down from 8.6 percent in 1981 and 11.9 percent in 1980 (figure 5).

\section{The End of the Battle against Inflation?}

Was the battle against inflation over? That is for others to judge. With the economy picking up and a projected rise in inflation, the FOMC raised the funds rate starting in May 1983 through August $1984 .{ }^{21}$ Some say that was the decisive action to establish the Federal Reserve's inflation credibility. In 1986, there was a whiff of deflation; headline inflation slowed to 1.7 percent by the end of the year on the back of falling energy and other

\footnotetext{
${ }^{19}$. The convention at the time was that global growth of less than 2.5 percent—on a purchasing power parity (PPP) basis used in the IMF's World Economic Outlook-was a recession. Growth in 1980 was 1.9 percent; in 1981, 2.3 percent; and in 1982, 0.7 percent, climbing only to 2.9 percent in 1983.

${ }^{20}$. Using the Federal Reserve Board staff's weights for the broad index for the foreign exchange value of the dollar and GDP data from national sources, foreign growth averaged 0.42 percent from the first quarter of 1982 to the first quarter of 1983.
}

\footnotetext{
". At the May 25, 1983, meeting there were five dissents, which was unusual. "These members also referred to the potentially disruptive international impact of rising U.S. interest rates. Anthony Solomon, Roger Guffey, and Frank Morris in particular believed that the already strong dollar in foreign exchange markets, the tenuous situation of some of the developing countries, the still fragile economic recovery in other industrial countries, and the continuing weak outlook for U.S. exports counseled against an increase in reserve restraint" (FRB 1983b). The other two dissenters were Nancy Teeters and Emmet Rice.
} 
commodity prices. Inflation averaged about 3 percent in 1991-93, and the funds rate was in the same range for about 18 months after the brief $1990-91$ recession. ${ }^{22}$

By 1982 the US inflation threat was reduced to a considerable extent. But the experience of the 1970s had been costly for the United States and for the world economy. The Federal Reserve was not the only central bank that pursued a monetary policy that was too easy in the 1970s, but it demonstrated a lack of leadership. Technical changes in financial markets, such as the growth of syndicated lending by banks to sovereign governments of developing countries, played a role in the crisis. Parallels between the global economic and financial crisis in 2007-09 and the economic and financial crisis of the early 1980s are stronger than is often appreciated today, in particular with respect to the role and responsibility of the United States in contributing to the crisis.

\section{The Third World Debt Crises}

The onset of the 1980s third world debt crises is conventionally dated to when the government of Mexico closed its foreign exchange market on Thursday, August 12, 1982, and the subsequent Mexican Weekend in Washington, during which US and Mexican officials cobbled together a rescue operation. Mexico had already devalued the peso in February. That devaluation was accompanied by the appointment of Jesus Silva Herzog as finance minister and Miguel Mancera as governor of the Bank of Mexico. They visited Washington-the Treasury, the IMF, and the Federal Reserve-essentially once a month starting in March until the crisis broke in August.

The FOMC discussed the Mexican situation in March and at each meeting for the remainder of 1982. At the end of April, June, and July, the Committee voted to allow the Bank of Mexico to draw on its swap line to pad its foreign reserves to meet the requirement to back its currency in circulation without revealing the precarious level of its reserves. The drawing was pure window dressing; the proceeds remained at the Federal Reserve Bank of New York. The FOMC was decidedly uncomfortable granting these requests, but saw dangers in turning them down. On August 4, the Bank of Mexico requested a non-window dressing drawing of the full $\$ 700$ million swap line. Its request was accompanied by a promise to go to the $\mathrm{MMF}$ for refinancing if it could not otherwise repay the drawing. ${ }^{23}$ Eight days later, the acute crisis phase was underway.

\footnotetext{
". That recession was largely caused by the run up in energy prices in the wake of Iraq's invasion of Kuwait and in the lead up to the first Gulf War. By this time, staff and the FOMC had a more coherent framework for calibrating policy: Look at the previous projection of growth in nominal GDP and adjust policy to keep it steady. As a result, part of the projected increase in nominal GDP would be taken in the form of an increase in inflation and part in the form of a decrease in the growth rate. This framework can be found in the material prepared for the August 21, 1990, FOMC (FRB 1990a).
}

\footnotetext{
${ }^{23}$. The basic framework for this drawing had been agreed at the end of July; I had received an oral commitment of Treasury support at that time. On August 4, Volcker received a written commitment from Secretary Regan to facilitate the Bank of Mexico’s repayment of the Federal Reserve by January 31, 1983, by permitting Mexico to draw on its swap line with the Exchange Stabilization Fund (ESF).
} 
Back in early May, 1 had accompanied Volcker to the Bank of International Settlements (BIS) for the monthly meeting of G-10 governors. Volcker warned his central bank colleagues that Mexico was likely facing an external financial crisis and that other developing countries would likely experience external financial problems as well.

Despite these warnings, when we contacted G-10 central bankers during the Mexican Weekend to say that the crisis had erupted, many officials were surprised. A senior official at the Bank of Japan asked why Mexico's crisis mattered to Japan. At that time, the BIS banking data were based on balance-of-payments accounting concepts and the location of the institution advancing credit; they were not based on the consolidated exposures across all the offices of a bank regardless of where they were located. 1 told my interlocutor that even the deficient location data revealed large Japanese bank exposures to Mexico. ${ }^{24}$

The basic framework used for the Mexican rescue was employed in several other cases. Governments and central banks, often acting through the BIS, provided countries with bridge financing while programs with the IMF were negotiated. In some cases, the drawings on the bridge loans did not occur until the economic reform program had been agreed with the Fund. Commercial banks were asked to agree to a standstill on principal payments while still receiving interest payments. As part of the financing of the IMF program, banks were asked to reschedule principal payments due, initially for the next year, and to make new loans to the country. ${ }^{25} \mathrm{~A}$ critical mass of the bank exposures to the country had to agree to these conditions before the IMF would disburse. $^{26}$

This was the Volcker Plan; it had a global approach. The template was used, with variations, for Brazil, Argentina, Yugoslavia, and the Philippines in 1982-83, and for several other countries.

The plan was developed at the Federal Reserve in November 1982, in large part by Charles J. Siegman working with Volcker (type B impacts). Volcker sold the plan to the Treasury and to James Baker at the White House. ${ }^{27}$ In later years, bank loans coming due over several years were rescheduled, and the interest rate on the

\footnotetext{
${ }^{24}$. In the wake of the financial crises of the 1970s, the US banking agencies began to collect "country exposure" data on the consolidated operations of US banks. As a consequence of the 1980s debt crises, we were able to convince other countries to do the same.
}

'. The rationale for adding to countries' external debts was that they were thought to be facing liquidity crises not insolvency crises (Cline 1983).

". This approach was later changed because of delays in bank approvals. The IMF adopted a policy that allowed it to lend to members with arrears to the banks.

". Deputy Secretary Tim McNamar took the lead at Treasury on these debt issues. He worked with Volcker on the plan and, in turn, relied on Deputy Assistant Secretary Tom Leddy, a civil servant in the great tradition of Treasury career officials, with whom 1 worked closely (see Volcker and Gyohten 1992, chapter 7, for their account of those days). 
rescheduled and new loans was lowered to LIBOR (London Interbank Offered Rate) plus 13/16, in principle barely covering the banks' cost of funds (Boughton 2001, chapter 9).

The Volcker Plan was successful in arresting the crisis, but economic and financial recovery proved to be more difficult. Consequently, in 1985 the United States put forward the Baker Plan. The Baker Plan sought to restore growth through structural reforms linked to greater use of World Bank assistance. Countries also were expected to have IMF programs. Banks were expected to contribute through rescheduling old loans and making new loans. ${ }^{28}$ Although Mexico and a number of other countries eventually participated in the plan, it too failed to achieve its economic objectives. ${ }^{29}$

The Baker Plan was followed in 1989 by the Brady Plan. The Brady Plan involved writing down and securitizing bank debt backed by a collateralization of near-term interest payments (via deposits in escrow accounts) and of full payment of principal, normally in 30 years (via zero-coupon bonds).

The Federal Reserve played three roles with respect to the Brady Plan. First, we convinced the Treasury to drop the all-or-nothing approach to debt reduction in favor of a menu approach, which included not only debt reduction but also debt service reduction and new loans at concessional interest rates. Second, we worked with the IMF, bankers, and countries to help implement the approach; Terry Checki at the Federal Reserve Bank of New York played a crucial role. ${ }^{30}$ Third, the Board of Governors approved the Federal Reserve Bank of New York's role in holding the escrow and collateral accounts for the Brady exchanges. This was an unusual role for the Federal Reserve to play, and the Board placed conditions on doing so, such as requiring the country to have an IMF program. ${ }^{31}$

The management of the third world debt crises of the 1980s has been criticized for imposing on the countries involved a decade of lost growth. Most countries suffered, though Chile after its crisis in 1982-83 was an exception. Could or should there have been better alternatives? Did the Federal Reserve and other central banks and governments around the world protect banks too much from the consequences of their mistakes? My answer is no at least in the first few years. No government facing an external financial crisis at that time even

\footnotetext{
". The Baker Plan focused on 17 countries, raised from an initial 15, of which five were not in Latin America (Cline 1995, chapter 5).
}

". Mexico had another crisis episode in 1988, again during an election year, and drew on the Federal Reserve swap and US Treasury swap lines on August 1 and repaid them on September 15 to pad its international reserves in connection with announcement of their levels on August 4 and September 1 .

${ }^{30}$. Meltzer $(2009,1182)$ incorrectly credits Checki with the design of the Brady Plan.

:One consequence of these conditions was that when Brazil and its bankers got around to completing a Brady package in 1994 without the support of an IMF program, the BIS was used to hold the collateral (Boughton 2012, 421-27). 
considered an open default or write-down of its debt to foreign banks. Policymakers were eager to get back to borrowing as soon as possible.

The Federal Reserve, the US bank supervisors collectively, and their counterparts in every advanced country exercised forbearance with respect to forcing banks to recognize actual or potential losses. That strategy was dictated by the scale of crisis affecting the banks and the condition of economies in the United States and elsewhere. The creditor banks ultimately took some losses. One might argue that the banks too would have been better off acting more quickly, but there was not much appetite for that. ${ }^{32}$

Crisis prevention efforts were stepped up during and after the outbreak of the third world debt crises. The United States and other countries agreed to increase IMF quota resources by almost half and to almost triple the size of the IMF's General Arrangements to Borrow (GAB), through which the IMF could borrow additional resources from certain members to finance its lending programs. The terms of the GAB were changed so that the extra resources were no longer reserved for IMF lending to the G-10 participating countries, but could be used to help finance any IMF program. The Federal Reserve presented to the US treasury the case for embracing this change.

Passage of the resulting legislation by Congress was not an easy task. It passed the House of Representatives by five votes. The Reagan administration had to "buy" approval by Democrats by agreeing to housing legislation that it did not support. The IMF legislation was incorporated into that legislation. Also included was the International Lending Supervision Act (ILSA), which tightened up some rules and regulations involving international lending, such as the ICERC process and accounting for origination fees (forcing them to be taken into earnings over the life of a loan rather than upfront). The legislation also called for the Federal Reserve and Treasury to undertake discussions with supervisors in other major countries to establish a common and higher level of capital for internationally active banks. Those discussions led to the 1988 Basel Capital Accord, in which the Federal Reserve played a major role.

IF staff at the Board, and by extension other parts of the Federal Reserve System, examined the evolving issues of sovereign debt. As shown in table 1, during the decade of the 1980s, 17 IFDPs were written on various aspects of financial crises, constituting 8 percent of the total. One of the most influential was an early paper by Michael P. Dooley et al. (1983), which examines the origins of debt problems of eight key countries and uses a simulation model to project their prospects for the rest of the decade. Dooley and his colleagues were among the first to point to the issue of capital flight, which could undermine any progress in reducing countries' current account deficits.

\section{The US Dollar and Current Account Deficits}

\footnotetext{
. The debates in the 1980s and 1990s about so-called private sector involvement and the role of debt rescheduling, re-profiling, and write-downs were similar to those still swirling today (IMF 2014).
} 
In addition to the third world debt crises, international economic policy discussions at the Federal Reserve in the 1980s were dominated by the emergence of a large US current account deficit, which peaked at more than 3 percent of GDP, and wide swings in the foreign exchange value of the dollar (figure 3).

During the first two months of 1981, the Desk bought substantial amounts of foreign currency as the dollar strengthened, having already covered the Carter Bonds. However, in late February, Undersecretary Beryl Sprinkel signaled that the Reagan administration and the Regan Treasury favored a minimalist approach to foreign exchange market intervention, and Desk's purchases stopped (Greene 1984b). In early April Sprinkel delivered congressional testimony outlining the Treasury's approach. Volcker had reviewed and toned down that testimony to emphasize that the minimalist approach to US intervention could still encompass operations to "counter disorderly market conditions."

Volcker's view was that the secretary of the Treasury was the chief financial officer of the United States and should set the framework for US intervention policy even if the Federal Reserve and Treasury had independent legal authority to operate in the foreign exchange market. ${ }^{33}$ In his oral remarks, Sprinkel expanded on his text and cast doubt on the need for the Federal Reserve's swap lines and for US foreign currency balances, part of which were subsequently used to subscribe to an increase in the US quota in the IMF (Pardee 1981). ${ }^{34}$

By June 1982, the dollar had appreciated by 25 percent in price-adjusted terms over the previous two years, and officials in other countries were complaining that the US unwillingness to cap the dollar's rise was undermining their own efforts to lower inflation. Consequently, at the G-7 Summit in June 1982, the United States agreed to a study of experience under floating exchange rates, including the effectiveness of exchange market intervention.

Philippe Jurgensen of the French finance ministry chaired the working group of officials. The Federal Reserve produced a number of background papers for the study (type $\mathrm{C}$ impact). ${ }^{35}$ Much of the effort was directed at trying to determine if sterilized intervention had been effective during the floating rate period, based on a portfolio balance model that assumes that securities denominated in different currencies are not perfect

${ }^{33}$. Indeed, on March 30, following the assassination attempt on President Reagan, I obtained Volcker's permission to authorize the Desk to buy dollars when we were unable to reach the Treasury. The Desk subsequently split the sales between System and ESF accounts.

${ }^{34}$. US intervention subsequently was minimal but not nonexistent. From April 1981 to January 1985, the Desk operated on 20 days.

. Ten US studies, including three by Margaret Greene of the Federal Reserve Bank of New York and one by a team from the Treasury, were later published as Staff Studies (Henderson and Sampson 1983). 
substitutes. ${ }^{36}$ The research results supply weak support for the effectiveness of intervention via the portfolio balance channel but also acknowledge the possibility of a signaling channel for effectiveness.

The working group's report contributed to a better understanding in official circles of the distinction between sterilized and unsterilized intervention and examined the issues associated with foreign exchange market intervention from a number of perspectives. On the effectiveness of intervention, the working group concludes: "[S]terilized intervention did not generally have a lasting effect, but . . . intervention in conjunction with domestic policy changes did have more durable impact" (Jurgensen 1983, 17).

The report of the working group went first to the Summit finance ministers, central bank governors, and representatives of the European Community, who issued a statement (1983) on April 29, 1983, in which they agreed "on the need for closer consultations on policies and market conditions; and, while retaining our freedom to operate independently, are willing to undertake coordinated intervention in instances where it is agreed that such intervention would be helpful." 37

The release of the working group's report and the associated statement on April 29 did not attract much attention either in the markets or at the FOMC table. Sam Cross (FRB 1983a), manager of the Desk at the time, commented that perhaps the nonreaction was because Secretary Regan immediately after the April 29 meeting said that US policy had not changed. It did not for another 21 months.

By May 1984, the dollar's real effective value had risen more than 30 percent from its level in July 1980, and the US current account deficit had ballooned to more than 2 percent of GDP. Although staff consistently projected that the dollar would soon start to depreciate, we continued to be wrong. Larry Promisel chaired a special FOMC presentation involving Peter Hooper, Peter lsard, and Dale Henderson on the deteriorating prospects for the US external position (FRB 1984). The presentation reviewed how the deficit had evolved to that point; presented some projections of the deficit if the dollar's value were to remain unchanged; and considered the implications of various alternative scenarios of (monetary and fiscal) policy induced or exogenous adjustment in the dollar. The presentation looked at the issue of sustainability in terms of the US international

\footnotetext{
". As was stressed by Michael Dooley at the Dallas conference, the effectiveness of the recent large-scale asset purchases by the Federal Reserve and other central banks relies on the same basic assumption. Researchers, in some cases using more modern techniques, have found substantial effectiveness in such purchases. However, recent central bank operations in domestic securities have been on wholly different scale than operations in foreign currencies in the 1970s and early 1980s.
}

\footnotetext{
- My hope in participating in the intervention study was that we would be able to preserve a role for sterilized intervention as a supportive tool of economic, including monetary, policy. In that we were successful, though I was disappointed by the weakness of the empirical results. Writing 20 years later (Truman 2003b), 1 conclude that the research still had not established a more robust role for intervention at least on the scale that it was then practiced.
} 
investment position, which was about to turn negative. The US current account deficit continued to expand through the end of $1987 .^{38}$

US exchange rate policy began to change in January 1985. On January 17, at a dinner meeting of the G-5 finance ministers and central bank governors at the Federal Reserve Board, in which both Secretary Regan and Secretary-designate Baker participated, it was decided to issue a statement inter alia to help ease the intense selling pressure on the British pound sterling. The statement referenced the 1983 Williamsburg G-7 summit's commitment "to undertake coordinated intervention in the markets as necessary." It was followed up by a small amount of coordinated intervention in which the United States (Federal Reserve and Treasury) participated.

The FOMC had a conference call on January 18, 1985, in which Volcker briefed the Committee on the G-5 meeting and the extent to which it was about sterling or the dollar. He observed: "1 think everybody would be relatively content, or more than relatively content, if the net result with intervention or without intervention was that the dollar ended up somewhat lower than it has been."

Governor Charles Partee commented, "I'm no great supporter of intervention as you know, but 1 do think the situation has become extreme enough that it is called for. 1 think it is a good move." (FRB 1985c)

For the February 1985 FOMC meeting, the staff again projected that the price-adjusted foreign exchange value of the dollar against the major currencies would depreciate under the weight of the rising current account deficit by about 15 percent over the next two years. The dollar finally peaked in March 1985 and then fell by 30 percent on the real broad index through early 1988 (figure 3). ${ }^{39}$

Market forces alone might have continued the dollar's decline beyond the summer of 1985, but they were reinforced by the Baker-inspired announcement by the G-5 finance ministers and central bank governors following their September 22 meeting at the Plaza Hotel in New York that "some further orderly appreciation of the main non-dollar currencies against the dollar is desirable."

Baker's initiative was in response to growing protectionist sentiments in the United States. Following the meeting in New York, an FOMC conference call was held on September 23 to explain that there could well be substantial intervention in subsequent days. Sam Cross's report to the FOMC on October 1 provided a full account of the effects of the announcement along with other events that produced a substantial decline in the dollar without a great deal of intervention (FRB 1985a).

\footnotetext{
${ }^{38}$. The continued deterioration of the US external position and its sustainability received extensive staff analysis for the rest of the decade (e.g., Danker and Hooper 1990; Helkie and Hooper 1987, 1989; Hooper and Mann 1987; Howard 1989; and Stekler and Helkie 1989). Staff of the Federal Reserve Board also participated during the 1980s in projects investigating policy rules that might promote better international economic policy coordination and results (e.g., Bryant et al. 1988; Bryant, Holtham, and Hooper 1988; Bryant, Hooper, and Mann 1993; and Hooper et al. 1990).

39. Against major currencies, the decline was 40 percent. In assessing this period in Truman (2006), I conclude that the message from the markets was that the US monetary/fiscal mix was flawed, the dollar had experienced a bubble, and concerns about protectionism were real.
} 
At the October 1985 FOMC meeting, concerns were raised about the implications of a "precipitous decline of the dollar" and a request was made for a special briefing. On the way to the IMF meetings in Seoul later in the week, Volcker-in what should have been treated as an off-the-record comment to Washington Post columnist Hobart Rowen — commented that "one could have too much of a good thing." ${ }^{40}$ At the subsequent November FOMC meeting, Axilrod chaired a presentation by Peter Hooper, David Stockton, Larry Slifman, and himself that outlined the possible path of external adjustment, the implications for the real economy, the dynamics of possible interest-rate and price changes, and associated monetary policy issues in terms of the risks to inflation and/or growth. Axilrod favored engineering a gradual adjustment of the dollar (FRB 1985b). Gradual adjustment was not in the cards, but neither was recession or inflation. Aided by the collapse of energy prices in 1986, inflation did not rise appreciably until late in the decade. Real interest rates, in particular long-term rates, did not increase much either (figure 5).

The dollar's depreciation went further and faster than anyone had anticipated. By early February 1986, it had declined by about 12 percent in real terms against the major currencies from its value in September 1985, and 20 percent from its peak the previous March. This triggered another instance in which international considerations impacted Federal Reserve monetary policy decisions in the form of the Board's aborted decision on February 24 to lower the discount rate. Volcker was concerned about the impact of a unilateral cut in the discount rate on the already weakening US dollar and voted against a change (type A impact). He was outvoted by Preston Martin, Martha Seger, Wayne Angel, and Manuel Johnson; the latter two had just joined the Board. Fortunately, changes in the discount rate were announced after the US markets closed rather than immediately, as is now the case. This allowed time not only for Volcker to draft his resignation letter and convey his intentions to Baker but also for cooler heads to prevail. The Board met again in the late afternoon and agreed that Volcker could have two weeks to negotiate downward adjustments in the German and Japanese discount rates prior to a reduction in the US rate, which occurred on March $7 .^{41}$

The depreciation of the US dollar continued. By the Februaryl987 FOMC meeting, the dollar was down 30 percent from its early 1985 peak in real terms against the major foreign currencies, and the staff projected that the depreciation would continue at a reduced pace at least through the end of 1988 (FRB 1987).

Starting in the fall of 1986, authorities in foreign countries became increasingly concerned about the pace and extent of the dollar's depreciation, in particular against the Japanese yen. On February 22, Baker and

\footnotetext{
. The quotation appeared in a column by Hobart Rowen a number of weeks later.
}

\footnotetext{
${ }^{41}$. I know of no definitive account of who initially agreed to delay the Board’s action and why. William Silber (2012, 254-58) provides a plausible version of the events.
} 
Volcker met with their counterparts from the other G-6 countries in Paris and announced in the Louvre Accord that "they agreed to cooperate closely to foster stability of exchange rates around current levels." ${ }^{42}$

In IF, we thought that it was a mistake to try to cut short the dollar's depreciation, in part, because the depreciation to date would not be sufficient to eliminate the US current deficit and, in part, because we anticipated that downward pressures on the dollar would continue to be intense. We sent a memorandum to Chairman Volcker outlining our arguments. He did not buy them. In Volcker and Gyohten (1992, 243), Volcker explained that he was concerned about the impact of further depreciation on the US inflation rate and subsequently on interest rates. In a discussion many years later, Volcker told me that he also was concerned about the broader impact of further dollar depreciation on growth in other countries (type B impact).

This announcement inaugurated a brief international experiment with target zones or reference ranges for exchange rates. ${ }^{43}$ The experiment quickly unwound: The reference rates were recalibrated several times, and by September 1987 they were ancient history as far as we at the Federal Reserve were concerned. ${ }^{44}$

The dollar continued to depreciate through the spring of 1987 and staged a brief recovery in the summer before tailing off again. At the September FOMC meeting, Chairman Greenspan's second, the federal funds rate was snugged up to support the dollar (type A impact).

The upward creep in US interest rates contributed to international financial tensions and led to public criticism by Baker of German economic and-in particular-Bundesbank monetary policy. Whether by coincidence or not, the US and global stock market crash followed on Monday, October 19. The Federal Reserve promptly eased its policy. However, other countries that were also affected by the global rush from equities did not immediately follow suit. International cooperation was not entirely absent. The relevant US authorities did consult with their counterparts almost daily.

The equity markets calmed down, but the dollar's slide accelerated. The G-7 ministers and governors issued a statement (for the first time negotiated without a meeting, hence a "telephone communiqué") on December 22 and followed up with substantial amounts of intervention to support the dollar to little avail. The delay in issuing the statement was because the other countries, Germany in particular, were waiting for the US

\footnotetext{
. The ltalian officials were invited, but boycotted when they learned that the G-5 had met the day before.
}

. The Louvre communiqué (G-6 1987) also states: "It is important that the newly industrialized developing economies should assume greater responsibility for preserving an open world trading system by reducing trade barriers and pursuing policies that allow their currencies to reflect more fully underlying economic fundamentals." Similar concerns led to the enactment of the Omnibus Trade and Competitiveness Act of 1988, which mandated that the Treasury twice a year report on developments in international economic and exchange rate policies in consultation with the Board and the International Monetary Fund.

“. Randall Henning (1994) argues—incorrectly in my view (Truman 2006, 194)— that the reference ranges continued through Baker's departure from the Treasury in August 1988 and gradually unraveled in 1989-90. It is possible that the framework persisted in the thinking of some Treasury officials, but their thoughts were never communicated to me in this manner. 
administration to agree with Congress on measures to cut the US budget deficit, which turned out to be quite modest after protracted negotiations in which Greenspan was an active participant (type A impact).

However, after the turn of the year, in the words of Cross (FRB 1988): "Central banks intervened in concert aggressively, visibly and noisily. The market had been looking for a signal, especially from the U.S., and these operations convinced many market participants that the G-7 countries were indeed now committed to halting the dollar's decline." The decline on a weighted-average price-adjusted basis did not bottom out until April, but the worst was over (see Truman 2006, 186-91, for a longer account of this episode).

\section{The Federal Reserve's Role in US Intervention}

The Federal Reserve was a full participant in US intervention operations associated with the decline of the dollar and attempts to halt that decline. But by the end of the 1980s change was in the air.

After the intervention operations in January 1988, the dollar's recovery persisted, perhaps aided by increases in the federal funds rate, which started in the spring of 1988 and continued through the middle of 1989. Largely following the desires of the Treasury, the Desk initially used the dollar's rise to rebuild US reserves of foreign currencies and later actively to resist the dollar's appreciation. ${ }^{45}$ The scale of these activities became controversial within the Federal Reserve, in part, because of the potential for losses on the Federal Reserve's share of US foreign currency reserves. In addition, the intervention appeared to be stepping on the gas at the same time the FOMC was stepping on the brakes with respect to consumer price inflation, which was creeping up to above 5 percent.

In response, Cross and 1 recommended to Greenspan that the staff conduct a study of Federal Reserve System foreign currency operations to review those operations from an institutional and historical perspective.

Greenspan agreed, as did the August 1989 FOMC (type A impact). ${ }^{46}$

We presented the Report of the Task Force on System Foreign Currency Operations to the March 1990 FOMC meeting. It contains an overview by Cross and me and 11 papers covering the legal, historical, and procedural aspects of Federal Reserve foreign currency operations; policy, strategy, and tactics; institutional frameworks for decision making here and abroad; resources for financing intervention, including the history of

\footnotetext{
45 . From January 1989 through April 1990, the US monetary authorities bought \$24.4 billion in foreign currencies operating on 114 of 346 business days (Truman 2006, 193).

${ }^{46}$. At that meeting, Johnson abstained from an increase in the size of the warehousing agreement for the Treasury or ESF from $\$ 5$ billion to $\$ 10$ billion, and he and Angel voted against an increase in the limit on the System's overall open position in all foreign currencies from \$18 billion to \$20 billion. Federal Reserve “warehousing” foreign currencies for the Treasury or the ESF involves a spot purchase of foreign currency from the Treasury or ESF with a simultaneous forward sale of that currency at the same exchange rate. It involves no exchange-rate risk to the System on the principal amount; such arrangements date back to 1962. See Henning (1999, 49-52) for some additional history.
} 
the "swap network;" and analytical issues. ${ }^{47}$ The papers were reviewed by a conference of System Research Directors. ${ }^{48}$

In the overview, Cross and 1 (Cross and Truman 1990) offer a number of summary observations:

- US exchange rate policy is set by the Secretary of the Treasury and has evolved since 1962 with the active participation of the Federal Reserve.

- The rubric under which US foreign currency operations are conducted, "countering disorderly market conditions," has been interpreted in an elastic manner.

- Federal Reserve foreign currency operations are routinely sterilized, but exchange market considerations have at times influenced the day-to-day implementation of monetary policy. ${ }^{49}$

- There is no evidence that Federal Reserve monetary policy had been subverted by inappropriate exchange rate considerations or by international exchange rate understandings.

The consensus on the limited effectiveness of sterilized intervention was as outlined earlier in this paper.

On the issue of warehousing foreign currency for the Treasury or its ESF, we advised against denying to the Treasury the US dollar resources it might need to purchase foreign currency.

In late February and early March 1990, pending the FOMC's discussion of the task force's report, Greenspan declined to participate in US purchases of yen and deutsche mark (Cross 1990). At the FOMC meeting, the report and related issues were extensively discussed (FRB 1990d, 46-84). The immediate questions for the Committee were whether it would approve a further increase in the limit on the System's overall open position in foreign currency from $\$ 21$ billion to $\$ 25$ billion and would approve a further increase in warehousing eligible foreign currencies for the Treasury or ESF from $\$ 10$ billion to $\$ 15$ billion.

The task force and its report may have cleared the air with respect to some of the issues surrounding Federal Reserve foreign currency operations, but a substantial degree of skepticism remained, as was noted in the Record of Policy Actions for the March meeting, released on May 18 (FRB 1990c). Wayne Angell, Lee Hoskins, and John LaWare voted against both actions largely on policy grounds. Angell and Hoskins also questioned the lack of congressional and constitutional authority to warehouse foreign currencies for the Treasury and ESF. Not by accident, the Record of Policy Actions introduced the questioning dissents by noting,

The papers are available in redacted form from the FOMC Secretariat. One paper (Edison 1990) was released as an IFDP; it reviews the literature on foreign exchange market intervention including its effectiveness. A second paper (Pauls 1990) appears in modified form as a Federal Reserve Bulletin article.

* In 1979 the System had an earlier related project on the implications of the exchange rate regime; see summary of 41 papers in Gray and Shafer (1981).

"The Treasury's operations via the ESF do not raise the question of sterilization because they do not impact the Federal Reserve's balance sheet. 
"Under a longstanding interpretation by the Committee and its General Counsel, warehousing transactions are open market operations in foreign currency that are authorized under the Federal Reserve Act."

Subsequently, on April 9, 1990, the Federal Reserve joined the Treasury in a symbolic purchase of yen at the request of the Japanese at a G-7 meeting in Paris. The US dollar peaked that month on a price-adjusted weighted-average basis against the major currencies and continued to decline in terms of the currencies of other important trading partners. See figure 6 for the three indices of the dollar price-adjusted foreign exchange value using the current staff methodology.

\section{THE 1990S: THE FEDERAL RESERVE GOES GLOBAL}

During the 1990s developments in the rest of the world attracted increasing Federal Reserve intellectual resources and attention, not to the exclusion of, but in addition to, domestic economic and financial developments. The US economy was not nearly as closed in real or financial terms as it had been in the 1960 s. Global political developments accompanied the economic and financial trends and also could not be ignored.

In some respects, these economic, financial, and political trends exacerbated disagreements within the Federal Reserve about the System's involvement in US foreign currency operations and about the Federal Reserve's role in international financial cooperation more generally. But the Federal Reserve's role was evolving.

\section{From Managed Floating to Limited Intervention}

Responding to concerns expressed by some members of the FOMC about Federal Reserve involvement in US foreign exchange operations, in particular about the Federal Reserve's warehousing facility for the Treasury and ESF, Greenspan persuaded the Treasury to liquidate some of its foreign currency holdings via sales to other central banks and to use some of its dollar proceeds to unwind some of the warehousing with the Federal Reserve. At the February 1992 FOMC meeting, the facility was unanimously reduced back to the traditional level of $\$ 5$ billion. This decision was accompanied by an exchange of letters between Brady and Greenspan that noted the reduction in the size of the facility, committed the Treasury to reduce its use of the facility by an additional $\$ 2$ billion, noted some other modest changes in terms, and expressed Brady's hope that the Committee would consider positively any future request to increase the size of the facility (see FRB 1992b).

Although the dollar declined a bit from May 1990 to early 1991, it appreciated again through June 1991. It again reached a low in September 1992 in the context of the turmoil in the exchange rate mechanism (ERM) of the European Monetary System (EMS).

Domestic financial markets were cheered after July 1992, when the FOMC cut the federal funds rate by 50 basis points. Foreign exchange market participants were less enthusiastic and were dismayed by remarks by Brady_after the Munich Economic Summit—-that were interpreted as welcoming dollar depreciation. These two events led US authorities to cooperate with several other countries to buy dollars on July 20 . Those purchases only temporarily arrested the dollar's decline, but operations continued through August 24. Bill 
McDonough, who was then manager of the Desk, and others in the Federal Reserve ultimately persuaded the Treasury to cease. This was another occasion in which the Federal Reserve was able to restrain the Treasury, in part, because the Federal Reserve could have declined to participate, which would subsequently have become public. Where we were less than prescient was in our lack of appreciation that the pressures on the dollar were primarily a reflection of tensions within the ERM that exploded in September.

The dollar fluctuated in a narrow range from September 1992 until early 1994, with only five days of US dollar purchases during 1993. Dollar purchases occurred on another five days during 1994, as the dollar weakened. Substantial purchases on June 24 triggered an extensive subsequent FOMC discussion on July 5 . In the end, Lawrence Lindsey and Jerry Jordan declined to approve the June transactions. Lindsey and Jordan (FRB 1992a) "agreed that the foreign exchange transactions conducted during the intermeeting period were authorized under the Committee's rules. Their dissents were based on their strong reservations about the efficacy of sterilized intervention in most circumstances, including those prevailing during the intermeeting period. In their view, to the extent that repeated intervention failed to achieve stated or perceived objectives, questions would tend to arise about the credibility of monetary policy more generally."

The real federal funds rate increased by almost 300 basis points (figure 7 ) and the price-adjusted dollar depreciated about 4 percent against all currencies and more than twice that much against the major currencies from January 1994 to March 1995. That was a bit of a puzzle. The FOMC and staff also were surprised that the interest rate on 10-year US government securities rose by about 200 basis points over the period of tightening. Our explanation at the time was that markets had overreacted to information that the global economy, not just the US economy, was growing more rapidly than had been expected.

The US dollar continued to weaken into July 1994, reaching lows against the yen and deutsche mark on July 19. In his testimony on July 20 , Greenspan said in a blunt response to a question worthy of his predecessor, Paul Volcker, "Any evidences of weakness in [the dollar] are neither good for the international financial system, nor good for the American economy" because of what they say about what is going on in the American system. $^{50}$

The next day, by prior design, Treasury Undersecretary Lawrence Summers stated in his testimony before the same committee:

The Administration believes that a strengthening of the dollar against the yen and the mark would have important economic benefits for the United States. It would restore confidence in financial markets that is important to sustaining recovery. It would boost the attractiveness of US assets and the incentive for longer-term investment in the economy, and it would help to keep inflation low. In addition, we believe-and this view is shared by other G-7 countries-a renewed decline in the dollar would be counterproductive to global recovery. (Fisher 1994, 2)

\footnotetext{
${ }^{50}$ Greenspan's formal testimony made the same point but less directly.
} 
These words were not followed by action in the foreign exchange market. There was no US intervention to support the dollar until early November. The support of the other G-7 countries was implicit. In January 1995 Secretary Rubin, who replaced Secretary Bentsen, morphed the policy from a "stronger dollar" to a "strong dollar" during his confirmation hearings-an important distinction that apparently is too subtle for most commentators.

The strong dollar policy has now been maintained by three US administrations for 20 years, and the Federal Reserve played a pivotal role in its articulation (type C impact). Of course, some observers want the United States to have_-and for the Federal Reserve to support_-policies for the dollar that are keyed to the state of the US economy and the US external accounts and point in different directions in different circumstances. For the US and the Federal Reserve's role in the global financial system, that is an impossible luxury.

The issue of US exchange rate and intervention policy, its relation to monetary policy, and the involvement of the Federal Reserve in the former again was discussed extensively by the FOMC following November 2-3, 1994, purchases of dollars. This discussion helped establish a stronger consensus in the Committee. The point was repeatedly made, and generally accepted, that the Federal Reserve exercised considerable influence over US intervention operations. The Treasury had the capacity to ignore Federal Reserve advice. But because the Federal Reserve could and had declined to participate in the past, its views acted as a brake on the Treasury. If the Federal Reserve were to take its skin permanently out of the game, the influence of its voice would be substantially weakened. Following this discussion, the November operations were unanimously approved. ${ }^{51}$

The Treasury and Federal Reserve operated jointly to support the dollar on eight occasions in the first eight months of 1995. The dollar bottomed out on a real effective basis in June or July 1995, depending on your choice of index.

The era of active US and Federal Reserve foreign currency operations ended in 1995. During the first two and a half years of the Clinton administration, US authorities operated 18 times in the foreign exchange markets, two fewer occasions than from April 1981 to December 1984 under the first Reagan administration. ${ }^{52}$ The Clinton administration, under the influence of the Federal Reserve and other factors, refrained from operating again until June 1998, with a substantial purchase of yen, and September 2000, with a substantial purchase of the new and weakening euro (type B impacts).

\footnotetext{
${ }^{51}$. At the same meeting $\mathrm{Al}$ Broaddus, as was his custom, dissented from approving the renewal of the Federal Reserve’s swap lines for 1995.

. The answer to the puzzle posed by Cooper and Little (2000) about why in 1994-95 with the dollar weakening there was not more Federal Reserve concern about the effects on US inflation is that (1) the depreciation was not all that significant (the dollar's real effective depreciation was only 8 percent over the 18-month period from its prior peak in January 1994 to its low August 1995), and (2) the inflation effects were viewed as modest—-staff forecasts of the CPI excluding food and energy fluctuated narrowly around 3 percent.
} 
US thinking about such operations had changed and the Federal Reserve played a major role in effecting that change. First, concerted (multilateral) operations have the greatest chance of success, which means that many countries have to turn on their off switches, and this raises the hurdles to such operations. This was the case in June 1998 and September 2000. Second, if one does operate, one should be prepared to operate in scale. Third, operations are more likely to have an impact if they are linked to other policy or economic and financial developments.

Contrary to the view in Michael Bordo, Owen Humpage, and Anna Schwartz (forthcoming, chapter 7), the evolution to a minimalist approach to Federal Reserve foreign currency operations in the mid-1990s was motivated primarily by pragmatic considerations of objectives, tactics, and effects rather than concerns about Federal Reserve independence and credibility. Some within the System and members of the FOMC strongly expressed the latter perspective, but their views were not decisive. As evidence, the Federal Reserve has operated in foreign exchange markets with the US Treasury three times since 1995, in 1998 and 2000 , as well as in March 2011, following the Japanese earthquake and tsunami. And there have been no changes in the FOMC's foreign currency authorization, directive, or procedural instructions. ${ }^{53}$

\section{Dismantling the Swap Network}

In 1996, the FOMC returned to the issue of foreign exchange market intervention in the guise of discussing the future of the Federal Reserve swap network. The swap network, at least historically, was associated with the Federal Reserve's involvement in foreign currency operations. Moreover, aside from the Bank of Mexico, no central bank had drawn on the swap network since the Swedish Riksbank did in 1981. The swap network was seen by many as an anachronism. Finally, with the European Central Bank (ECB) scheduled to start operations on January 1, 1999, at a minimum swap arrangements with the central banks that would be subsumed into the euro area would have to be renegotiated. Against this background, Peter Fisher, Don Kohn, and 1 (1996) sent a memorandum to the FOMC discussing issues and alternatives. The topic was discussed on July 2, 1996 (FRB 1996b, 95-113).

FOMC sentiment generally favored dismantling the swap network. But three countervailing arguments were advanced. First, the swap network was seen by some as symbolic of Federal Reserve engagement with other central banks, and most FOMC members were reluctant to send the wrong signal about the Federal Reserve's continued interest in international monetary cooperation. Second, a few members spoke with considerable foresight about the potential dollar liquidity needs of foreign central banks in the future. In light of potential liquidity problems of Japanese banks with large presences in the United States, the Federal Reserve had recently entered into an agreement with the Bank of Japan to use Japan's US Treasury securities as a backstop for borrowings by Japanese banks from the discount window. The staff paper discusses the possibility of

\footnotetext{
${ }^{53}$ The FOMC had an extensive discussion of the September 2000 operation in euro, and some members advocated changing the framework governing those operations. That view was not widely supported (FRB 2000), and the operation was unanimously approved.
} 
establishing a reverse repurchase facility for foreign central banks. ${ }^{54}$ Third, in this connection a few members mentioned not only international payment system issues but also the implications of closing down the swap network in whole or in part for the international role of the US dollar.

The conclusion was that Greenspan and McDonough, who had become President of the Federal Reserve Bank of New York, should consult with the president of the Bundesbank and the governor of the Bank of Japan at the next BIS meeting, which they did. They reported to the August FOMC meeting (FRB 1996b, 4-8) that the Bundesbank was receptive to dismantling the swap network, but it was reluctant to do so until the membership in the ECB had been established, and the Bank of Japan was not. The Committee agreed to return to the issue at a later date.

At the September 1998 FOMC meeting, Fisher and 1 (1998) presented a memorandum to the FOMC in which we reported that the Bank of Japan was less reluctant and other central banks were willing to dismantle the swap network. Consequently, with the exception of the swap arrangements with Mexico and Canada, the Federal Reserve's swap network, first established in 1962, was terminated as of the end of 1998. A coordinated announcement was made on December 23, 1998, in connection with the release of the minutes of the November 17 meeting (FRB 1998b).

The FOMC's decision did not address the swap arrangements with Mexico and Canada. In recent years, the use of the swap line with the Bank of Mexico had sparked most of the controversy within the FOMC on this topic. Some FOMC members and my successor as director of the Division of International Finance, Karen Johnson, subsequently endeavored to dismantle those arrangements, but without success.

The irony is that the swap network was resurrected for use to provide liquidity in connection with the millennium (Y2K) changeover, but was not needed. It was again revived and used in the wake of the attack on the World Trade Center on September 11, 2001. And it was used extensively and with an expanded set of participating countries during the global financial crisis starting in 2008. Portions of the network are again permanent and are available now without limits on the size of possible drawings, though activation still requires mutual consent.

Cooper and Little $(2000,102)$ are correct in their comment on the 1998 FOMC decision and the role of the swap network in facilitating the Federal Reserve's role as international lender of last resort: "World politics are not yet as global as world financial crises." In 1998, the FOMC may have been in denial.

\section{The US External Accounts}

After a brief surplus in 1991, the US current account moved back into the red. By late 1996, the staff was projecting a deficit of more than 2 percent of GDP. A deficit of that size did not immediately materialize, but

\footnotetext{
${ }^{54}$. Some interest was shown in this proposal, but it was not acted upon.
} 
the trend was sufficiently disturbing that the staff under Johnson began a fresh, exhaustive look at prospects for the US external position. The primary focus was the sustainability of the US current account position in a projected environment in which US growth was expected (incorrectly) to be stronger than growth in the rest of the world. In addition, trends in US exports and imports appeared still to be affected by the finding of Hendrik Houthakker and Stephen Magee (1969) that the income elasticity of foreign demand for US exports was less than the income elasticity of US demand for imports. The bottom line was that whatever the definition of a sustainable US international investment position in terms of the appetite of the rest of the world for claims on the United States, substantial continuous real dollar depreciation would likely be necessary to maintain that position. The secondary questions were whether markets would bring about the adjustment and whether policy — in particular US fiscal policy — would be a necessary complement to facilitate the adjustment.

The results of this study and related research were presented to the Board of Governors and to the Treasury. The substance made its way into Board and FOMC briefings. But the study was not formally presented and at the moment is not available to the general public. ${ }^{55}$

Johnson recently shared with me two observations about this topic: First, there was the lack of clear thinking from those who demanded that the United States narrow its current account deficit but did not want to see a drop in the dollar. They claimed a change in US fiscal policy magically would pass through to the current account deficit. But we know better. A tighter US fiscal policy works through the dollar via its impact on interest rates and through income just as any shock would. So either the United States goes into recession, the dollar adjusts, or both. If you define successful adjustment to mean that the United States gets back to full employment, then the dollar is the principal channel.

Second, at most of the discussions at BIS and IMF meetings on the topic of US external adjustment, the representatives of each country wanted the United States to adjust, but they did not want to be the counterpart to that adjustment. The Federal Reserve is the central bank of the nth, or residual, currency in the international monetary system, with even less capacity to influence the adjustment process than it had under the Bretton Woods system; see Johnson (2014) for elaboration.

The project directed by Johnson was not the last such effort at the Federal Reserve Board. William Helkie coordinated a later project in this period. As part of both the Johnson and Helkie projects, the staff devoted greater attention and analysis to the US financial account and associated issues than in earlier work (e.g., Ahearne, Griever, and Warnock 2000; Warnock and Mason 2000). In addition, Caroline Freund (2000) produced her well-known paper on the experiences of industrial countries with current account adjustments: the point at

\footnotetext{
55. One paper that was an input to this project was released as an IFDP (Hooper, Johnson, and Marquez 1998) and later appeared with the same title in Princeton Study in International Economics 87 (2000), Princeton, NJ: International Finance Section, Department of Economics, Princeton University. Catherine Mann (1999) also drew on her work on this project before she left the staff of the Federal Reserve Board.
} 
which reversal often begins ( 5 percent of GDP), the typical negative impact on growth, and associated real depreciation (10 to 20 percent).

\section{External Financial Crises and International Relations}

The 1990s saw its share of external financial crises. The Federal Reserve played a role in addressing many of them and in their aftermaths. Moreover, during this decade the Federal Reserve became increasingly involved with countries, their central banks, and institutions outside its traditional G-10 (plus Mexico) circle.

\section{The Mexican Crisis}

The North American Free Trade Agreement (NAFTA) with Mexico and Canada was the first order of Mexican business for the Clinton administration. A $\$ 6$ billion contingency swap facility, equally shared between the Treasury and the Federal Reserve, for the Bank of Mexico was available to activate if the legislation did not pass. It narrowly passed the House of Representatives by 234-200.

Subsequently, the North American Financial Group (NAFG) was established as a consultative body alongside NAFTA, with an associated North American Framework Arrangement (NAFA) involving increased Treasury and Federal Reserve swap lines with Mexico of \$3 billion each; a Canada-Mexico swap line of C\$1 billion; and the existing Federal Reserve swap line with the Bank of Canada of \$2 billion. Before the NAFA was formally signed on April 26, 1994, Mexican presidential candidate Luis Donaldo Colosio was assassinated on March 23. The Federal Reserve and Treasury immediately agreed to provide a special swap facility, as had been arranged the previous November, for the Mexicans to draw upon to support their markets when they reopened on March 25. The facility was announced but not drawn upon.

Mexico was again running a current account deficit in part because its exchange rate-based stabilization policy did not allow the peso's crawl to keep up with the widening inflation differential between Mexico and the United States. As in 1976, 1982, and 1988, the issue was whether Mexico's policy regime would hold until after the Mexican presidential election and the expected handover from Carlos Salinas to Ernesto Zedillo on December 1. In connection with the election on August 21, the Federal Reserve coordinated a contingent multilateral support package of $\$ 12$ billion, half of which was to come from the existing Treasury and Federal Reserve swap arrangements and half was to be provided by other central banks through the BIS. It was understood that if Mexico drew it would be obligated to reexamine its exchange rate policy (FRB 1994) with the understanding, at least on the US side, that it would lead to an accelerated depreciation of the peso and preferably more aggressive actions to address Mexico's macroeconomic problems.

Mexico got through the election without the need to activate the facility. But pressure mounted again after the FOMC, on November 15, raised the target for the federal funds rate by 75 basis points. This was a surprise to the market and to the Bank of Mexico, which chose not to match the increase. Increased pressure on the peso resulted, and a weekend of telephone consultations between Mexican and US authorities, including those at 
the Federal Reserve, followed. On Sunday night, November 20, Secretary Bentsen delivered the US consensus advice to his Mexican counterpart Pedro Aspe: Adjust your exchange rate policy sooner rather than later. The advice was rejected. Three weeks later Summers called me and said, "We were wrong: nothing has happened."

1 replied, "Wait and see."

Sure enough, on Tuesday, December 20, as the FOMC was meeting, the Mexican authorities announced that they had moved their intervention band 15 percent but were retaining the rate of crawl of 4 centavos a day.

The new exchange rate regime did not hold, in part, because it was not supported by any other policy measures or an announcement that Mexico would turn to the IMF for help. The Federal Reserve, in early January, allowed the Bank of Mexico to draw on its swap line after Mexico had agreed to go to the MFF and promised henceforth to announce its reserve holdings at least once a month. However, the run on the peso continued. The Zedillo administration's second finance minister during its first month in office, Guillermo Ortiz, visited the Treasury and Federal Reserve and asked for help.

After considering several alternatives, the Treasury proposed a $\$ 20$ billion package of loan guarantees for Mexico. Accompanying the proposal, which was reviewed by an interagency group before going to President Clinton on the evening of January II, was a Federal Reserve staff analysis, at the Treasury's request. It concluded that in a worst-case scenario of knock-on effects to other countries, the Mexican crisis could lead to a 2 percent decline in US GDP from the current trajectory. ${ }^{56}$

Clinton accepted the Treasury proposal. For much of the remainder of January, Rubin, Summers, and Greenspan were on Capitol Hill trying to sell the package, which had grown in size to $\$ 40$ billion. Although congressional leadership had initially endorsed the proposal, the selling job became increasingly tough.

1 suggested to Summers that the Treasury might use the ESF as an alternative. He said Treasury had explored that option, but there were not enough dollars in the ESF. 1 noted that some of the ESF's holdings of deutsche mark and yen could be warehoused with the Federal Reserve to provide the ESF with more dollars if necessary, as long as the FOMC were willing to expand the warehousing facility (which 1 certainly could not guarantee). Summers subsequently discussed this approach with Rubin and Greenspan, and this second plan was adopted. It involved a $\$ 20$ billion swap line for Mexico from the Treasury's ESF, an augmentation of Mexico's $\$ 7.5$ billion IMF program by $\$ 10$ billion, and an increased commitment from the BIS for a windowdressing swap arrangement of $\$ 10$ billion in place of the previously agreed $\$ 5$ billion.

The second plan was announced on the morning of January 31. In the afternoon, I briefed the FOMC on the plan, its rationale, and the proposed facilitating role for the Federal Reserve (FRB 1995). In the end, only Larry Lindsey and Tom Melzer dissented from the decision to increase the size of the warehousing facility to $\$ 20$ billion, but a number of other governors and presidents were unhappy (type B

${ }^{56}$. Bob Woodward (2000) incorrectly wrote that the analysis used the word would instead of could. Despite the fact that I had told him that the analysis had used the word could (in good central bank speak), Woodward insisted in writing would unless I produced the document; I could not do this, because I was then at the Treasury. 
impacts). No one could be confident that the plan would work, much less what the consequences for the Federal Reserve would be either way. The plan worked better than anyone expected; by the middle of 1995, Mexico had turned the corner under Zedillo. Indeed, in 2000, Mexico did not experience a financial crisis in its presidential election year for the first time since 1970. Staff in the division of international finance also wrote a number of ex post assessments of the Mexican crisis and its experience with a type of exchange-rate based stabilization policy. Several were written by Steve Kamin, a future division director who did yeoman service during the Mexican crisis (Kamin 1996 and Kamin and John Rogers 1996 and 1997).

In the wake of the Mexican financial crisis, Federal Reserve representatives participated in two efforts to improve what later became known as the "international financial architecture" (type C impacts). A central bank group and, later, the G-10 deputies of finance ministers and central bank governors endeavored to learn the lessons from Mexico's sovereign liquidity crisis. This initiative resulted in a report (G-10 1996) that laid the initial groundwork for what are now known as collective action clauses; they were not embraced broadly until the early part of this century.

Second, the Federal Reserve worked with the Treasury to design and gain international, and ultimately congressional, approval of the IMF's new arrangements to borrow (NAB). This mechanism for permanently adding to the capacity of the IMF to borrow from certain members in addition to their quota subscriptions was endorsed in principal at the Halifax G-7 summit in 1995 but did not become effective until the end of 1998. The $\mathrm{NAB}$ was built on the model of the GAB except the group of participating countries was expanded to include many more members, including emerging market and developing countries.

\section{Asian Financial Crises}

During the Asian financial crises of 1997-98, Federal Reserve staff, including Reserve Bank staff, worked with the Treasury on programs for various affected countries, but the Federal Reserve in general had a secondary role. The FOMC discussed the Asian crises at their meetings in the summer and fall of 1997. The principal issue was the implications for the US outlook. In the Greenbook forecast of November 11, 1997, we had real GDP growth in developing countries at 2.4 percent for 1998, down from 5.4 percent in 1997 and bouncing back to 4.3 percent in 1999 (FRB 1997). A year later, the three figures were 5.1, - 1.8, and 1.1 percent respectively (FRB 1998a)..$^{57}$ We got that forecast wrong too. By November 1999, the data

\footnotetext{
${ }^{57}$ One explanation for our error was that the crisis countries refused to accept in the background material for the IMF programs forecasts of negative growth. This was true for Thailand and Korea in particular. Another explanation is that we forgot the devaluations can be contractionary in particular when they are associated with crises in the country's financial system. Even if exports expand and imports contract, domestic investment tends to collapse.
} 
and staff forecast were 5.1, -0.3, and 4.4 percent respectively (FRB 1999a). The downturn was not quite as deep as we once thought it might be, and the bounce back was substantial. 58

The Federal Reserve role changed at the end of the year, when the initial program for Korea failed to arrest its crisis. Korea had run down its foreign exchange reserves through investments in Korean banks that had lost access to dollar financing and through defending its exchange rate before the crisis broke in November. Consequently, in December, financing from the IMF was coming in the front door and was being paid out to foreign banks through the back door via Korean banks. This situation was not sustainable.

Treasury Assistant Secretary Tim Geithner and 1 proposed to Rubin and Greenspan that we seek international cooperation on a standstill and rollover of payments due from Korean banks to US and other foreign banks and to a subsequent re-profiling of those claims. Rubin and Greenspan agreed it was worth a try (type B impact). The G-7 ministers and governors launched the plan on December 24, 1997 (G-7 1997). The announcement concludes: "A successful program will require a continued sustained commitment to reform by the Korean authorities, appropriate financial support from the official sector as outlined above conditioned on the strong policies necessary to restore confidence, and a successful effort by the Korean authorities to secure longer term financing from private creditors and the international capital markets." For about six weeks, 1 chaired a daily international conference call among central banks and the IMF to monitor progress in getting banks to agree to the standstill and, later, compliance with their commitments.

The official international financial community, with the participation of the Federal Reserve, responded to the Asian financial crises with an additional set of reports on reforming the international financial architecture (BIS 1998). The reports covered enhancing transparency and accountability, strengthening financial systems, and managing international financial crises. The Federal Reserve also was a driving force behind the establishment in 1999 of the Data Template on International Reserves and Foreign Currency Liquidity. It was designed to ensure that countries accurately and regularly report their international reserves to the market and their own citizens, as Mexico and later Thailand and Korea had not done.

\section{Engagement with other Countries and Regions}

In October 1989 Greenspan, at the request of the White House, went to Moscow to meet with Leonid Abalkin (charged by Mikhail Gorbachev to try to reform the Soviet economy) and his colleagues. ${ }^{59}$ Our advice was to develop a capital market to support increased domestic investment. But it was too late for reform to save the

\footnotetext{
${ }^{58}$ Steve Kamin, who by then had principal staff responsibility for the forecasts for emerging market and developing countries, though ultimate responsibility was with the division director, wrote a nice paper (Kamin and Marc Klau 1998) examining the issue of contractionary devaluations that concluded that they were not generally contractionary at least in the long run.

59. I accompanied Greenspan along with Robert Zoellick, who was then at the State Department as economic counselor and undersecretary for economic and agricultural affairs. See Greenspan (2007, chapter 6) for an account of this visit.
} 
Soviet economy and system. A month later the Berlin Wall came down. Two years later the Soviet Union was dissolved.

The collapse of the Soviet Union led to an extensive involvement of the Federal Reserve Bank of New York with the reform government of Boris Yeltsin that focused on the Russian banking system. It also led to an international cooperative effort involving many people in the Federal Reserve System to help Russia and the post-Soviet states establish credible and effective central banks in the wake of the hyperinflation that accompanied the collapse of the ruble area. Nathan Sheets, a future director of the division of international finance, started his career at the Federal Reserve covering Russia and the transition economies formerly in the orbit of the Soviet Union. Among his many papers was one that examined the experience of countries in transition with capital flight (Nathan Sheets 1995). A second examined the export performance of the transition economies (Sheets and Simona Boata 1996).

The fall of the Berlin Wall and the subsequent unification of Germany led to several important and penetrating IFDPs by Alexander and Gagnon (1990); Adams, Alexander, and Gagnon (1992); and Gagnon, Masson, and McKibbin (1996). These papers demonstrate that German monetary and political unification was an asymmetrical demand shock that put strains on fixed exchange rates within the exchange rate mechanism (ERM) of the European monetary system.

Federal Reserve Board economists also were among the few US-based economists who took seriously the prospect of a European Economic and Monetary Union (EMU) and wrote a number of papers on its implications and prospects. Jay Bryson (1993) questions the limits on the flexibility of fiscal policies suggested in the Delors Report. Karen Johnson (1994) looks at the implications of EMU for the dollar and concludes that its effect on the international role of the dollar would be benign as long as the US economic policy in general and the Federal Reserve policy in particular appropriately discharged their mandates. Edison and Kole (1994) look at the lessons from the 1992-93 ERM crises for the path toward the establishment of the euro.

The Federal Reserve's extensive relations with China started in the spring of 1980, when a 25-person delegation from China representing the People's Bank, Bank of China, and Agricultural Bank of China visited the Federal Reserve Board as well as Federal Reserve Banks and offices in New York, Chicago, Houston, and San Francisco. A few months later, Volcker led a six-person group, on a return visit. Soon every member of the Board and most presidents of Reserve Banks had visited China and hosted delegations from the People's Bank of China. In 1994 Greenspan led an interagency visit to the People's Bank of China, then headed by Zhu Rongji, who was later premier. The Summers Treasury and Clinton White House enlisted Greenspan's support for granting China permanent normal trade relations in the context of China's joining the World Trade Organization.

On August 17, 1998, a year after the outbreak of the Asian financial crises, Russia announced that it would float the ruble and suspend payments on certain debts. Financial markets reacted adversely; many market participants had thought Russia was too nuclear to fail. Financial conditions tightened further over the next 
couple of weeks. The resultant deteriorating global economic and financial outlook led Greenspan, after consultation with colleagues at the Federal Reserve Bank of Kansas City symposium in Jackson Hole on August 27-29, to declare in a subsequent speech at Berkeley on September 4:

[1]t is just not credible that the United States can remain an oasis of prosperity unaffected by a world that is experiencing greatly increased stress. Developments overseas have contributed to holding down prices and aggregate demand in the United States in the face of strong domestic spending. As dislocations abroad mount, feeding back on our financial markets, restraint is likely to intensify. In the spring and early summer, the Federal Open Market Committee was concerned that a rise in inflation was the primary threat to the continued expansion of the economy. By the time of the Committee's August meeting, the risks had become balanced, and the Committee will need to consider carefully the potential ramifications of ongoing developments since that meeting. (Greenspan 1998)

The market got the signal, but it was not enough to relieve market tensions, which were intensified by the problems of Long-Term Capital Management. The FOMC subsequently reduced the federal funds rate by 75 basis points. The US and world economies were being strongly affected by the slowdown in global growth (type C impact). ${ }^{60}$

Symbolic of the Federal Reserve's expanding engagement with the rest of the world was the decision to take up the Federal Reserve's seats on the Board of the Bank for International Settlements in 1994. ${ }^{61}$ Once on the BIS board, the Federal Reserve, represented by Greenspan and McDonough, successfully pressed to expand BIS membership beyond European and a few other central banks.

The Federal Reserve also was a key participant in the creation of the Financial Stability Forum (FSF) in 1999, which became the expanded Financial Stability Board in 2009, to monitor international financial developments, coordinate regulatory activities, and broaden existing oversight to include finance ministries. Roger Ferguson was the second FSF chair, from 2003 to 2006. Federal Reserve officials from both the Federal Reserve Bank of New York and Board of Governors had participated in the BIS Euro-currency Standing Committee since its establishment in 1971. It was the principal international forum for discussing what are now known as "macro-prudential" issues. In 1999 the committee was renamed the Committee on the Global Financial System. Donald L. Kohn served as its chair from 2006 until his retirement in 2010, at which point William C. Dudley, president of the Federal Reserve Bank of New York, succeeded him. ${ }^{62}$

\footnotetext{
${ }^{60}$. In the fourth quarter of 1998, the US export-weighted index of global growth over the previous four quarters had reached its lowest level since the first quarter of 1983.
}

". See Charles J. Siegman (1994) for a history of the Federal Reserve's involvement with the BIS up until September 1994.

\footnotetext{
62. The Federal Reserve was a charter member of the Basel Committee on Banking Supervision and supplied two of its chairs Jerry Corrigan (1991-93) and Bill McDonough (1998-2002). The Federal Reserve was also a driving force behind what is now
} 
By the turn of the 20th century, the Federal Reserve had become fully engaged with the world. International concerns were too numerous to be managed primarily by the president and staff at the Federal Reserve Bank of New York, one governor (Dewey Daane in the late 1960s and early 1979s and after him Henry Wallich) of the Federal Reserve Board, and occasionally the chairman. All governors had acquired important international responsibilities, and Reserve Bank presidents were much more engaged internationally as well.

\section{CONCLUDING OBSERVATIONS}

By 2000 the principal changes in the four areas addressed in this paper were that the issues were now spread on a global canvas and the Federal Reserve had become the principal artist. The Federal Reserve was deeply enmeshed in an economically and in particular financially globalized world.

1 have identified in this paper 18 instances in which either $(A)$ developments in the global economy or policies of other countries substantially affected Federal Reserve decision making or activities; (B) Federal Reserve decisions were undertaken primarily to support other countries but with commensurate benefits for the United States; or (C) occasions of decisions in win-win cooperation.

The first category comprises

1973 oil shocks;

1978 dollar rescue package;

1979 adoption of the new operating procedures;

February 1986 discount rate decision;

September 1987 tightening to support the dollar;

December 1987 fiscal package and related G-7 announcement; and

1989-90 tensions over intervention and Federal Reserve monetary policy.

In the second category are

Swap drawings by ltaly, Mexico, and United Kingdom in 1974-76;

Monetary policy easing in 1982;

Third world debt crises of the 1980s;

- Support for the Louvre Accord;

1994-95 Mexican crisis;

Organization of the Korean standstill in 1997-98; and

the BIS Committee on Payment and Settlement Systems, supplying an early chair, Wayne Angell (1988-90), and more recently Tim Geithner (2005-09) and Bill Dudley (2009-12). 
1998 and 2000 intervention purchases of yen and euro.

The final category includes

1983 Jurgensen report on exchange market intervention;

July 1994 Greenspan statement on the dollar;

Post-Mexico 1994-95 cooperation on international financial architecture issues and

September-October 1998 FOMC easing.

Some may disagree with my identifications, classificadtions and interpretations. Others may add to this list, which is not exhaustive. My view is that these examples are sufficient to support my thesis that the Federal Reserve by 2000 had emerged as the closest the world has to a global central bank. No other central bank was as engaged with the global economy and financial system.

Long before 2000, the Federal Reserve had implicitly embraced the view that inflation should be the central bank's primary objective and is essentially a homegrown product. As 1 advocated in Truman (2003a), the Federal Reserve in 2012 formally adopted along-term inflation goal. Today the only question is whether one could have too little as well as too much inflation.

By the mid-1990s, the issue of Federal Reserve involvement in US foreign exchange operations had been resolved through a combination of Federal Reserve influence on US intervention policy, the emerging consensus among most advanced countries on the limited role that such operations should have in macroeconomic policy management, and an end for most advanced countries of their fear of floating.

By 2000 the associated issues of the US current account position and the sustainability of the US international debt position had largely receded from receiving high-level policy attention within the Federal Reserve. However, those concerns reemerged after 2000.

With the growing globalization of financial markets, the international role of the US dollar in 2000 was more significant than it had been within the narrow confines of official currency arrangements that characterized the Bretton Woods period. Other currencies, including the nascent euro, the waning yen, and the yet to be internationalized Chinese renminbi, were acquiring roles in the international financial system alongside a large number currencies of smaller economies. But the international financial system had become so large and integrated that even as the US dollar's share of international financial flows and stocks declined somewhat, the dollar's absolute importance, and with it the responsibilities of the Federal Reserve, expanded.

The dollar's increased international role meant that the United States and the Federal Reserve had even less scope to employ exchange rate policy directly or indirectly to address actual or potential concerns about the sustainability of the US external accounts. The US dollar's role may be privileged but, as illustrated by US preference for a passive strong dollar policy, the privilege is constrained.

By the end of the 1990s, the Federal Reserve could run from global economic and financial developments but it could not hide from them. The Federal Reserve had become heavily involved in financial crises of a 
growing number of countries around the world. This expansion mirrored the emergence in the 21st century of the Federal Reserve as the closest the world has to a global central bank.

My view of Federal Reserve involvement in the external financial crises during the last third of the 20th century, as well as now, is that central banks should do what they think right in terms of the overall common good and deal with the consequences in ex post assessments. You do not keep the fire trucks in the firehouse when the city is burning even if the risk is that you will save the underserving and lose firefighters, trucks, and firehouses as an indirect consequence of cooperation internally or externally.

The Federal Reserve should interpret the global common good broadly. Because of the increase in international economic and financial integration, its existing mandate can accommodate such an interpretation. At the conclusion of the sixth meeting of the strategic and economic dialogue on July 11, 2014, Chair Yellen agreed to include in the U.S.-China Joint Fact Sheet (US Treasury 2014): "The Federal Reserve is sensitive to the effects of its policies on the international financial system. A key goal of the Federal Reserve is to maintain financial stability both domestically and internationally." This statement of the Federal Reserve's posture does not mean it will put the interests of one or more other countries before the interests of US economic and financial stability. One practical reason is that the interests of countries will not always coincide; what is best for India may not be best for Canada or Turkey. But the Federal Reserve take a broad view of its responsibilities because it has a shared goal and responsibility for economic and financial stability domestically and internationally. Nevertheless, the Federal Reserve cannot solve all US domestic economic and financial problems. Likewise, it cannot do so for the rest of the world.

In my oral presentation of the Foreign Exchange Task Force report to the FOMC in March 1990 (FRB 1990b), 1 said, "I believe that the Federal Reserve's cooperation with the Treasury in exchange rate matters, on the whole, has served the System's and the nation's interest." That was my view with respect to US intervention activity at the time, and it is my view today on the broad range of Federal Reserve international activities that involve its working with the US Treasury and other institutions around the world.

The nation is served, and the interest of the Federal Reserve is served, by economic and financial policies of high quality. The Federal Reserve is right to employ its intellectual and other resources to contribute to better US and global economic and financial policies even when those policies do not lie narrowly within the Federal Reserve's mandate. The Federal Reserve is independent within the government. It enjoys a degree of insulation from short-run political pressures, and it benefits from a stable institutional structure. Along with these protections, the Federal Reserve has commensurate responsibility for the full range of economic and financial outcomes produced by governmental processes, domestically and internationally.

\section{REFERENCES}

Adams, Donald B., and Dale W. Henderson. 1983. Definition and Measurement of Exchange Market Intervention. Staff Studies 126. Washington: Board of Governors of the Federal Reserve System. 
Adams, Gwyn, Lewis S. Alexander, and Joseph Gagon. 1992. German Unification and the European Monetary System: A Quantitative Analysis. International Finance Discussion Papers 421 (January). Washington: Board of Governors of the Federal Reserve System.

Ahearne, Alan G., William L. Griever, and Francis E. Warnock. 2000. Information Costs and Home Bias: An Analysis of US Holdings of Foreign Equities. International Finance Discussion Papers 691 (December, latest version May 2002). Washington: Board of Governors of the Federal Reserve System.

Alexander, Lewis S., and Joseph E. Gagnon. 1990. The Global Economic Consequences of German Unification. International Finance Discussion Papers 379 (April). Washington: Board of Governors of the Federal Reserve System.

Bayoumi, Tamim, and Trung Bui. 2010. Deconstructing the International Business Cycle: Why Does A US Sneeze Give the Rest of the World A Cold? IMF Discussion Paper WP/10/239 (July). Washington: International Monetary Fund.

Bayoumi, Tamim, and Trung Bui. 2012. Global Bonding: Do U.S. Bond and Equity Spillovers Dominate Global Financial Markets? IMF Discussion Paper WP/12/298 (December). Washington: International Monetary Fund.

Bayoumi, Tamim, and Andrew Swiston. 2007. Foreign Entanglements: Estimating the Source and Size of Spillovers Across Industrial Countries. IMF Discussion Paper WP/07/182 (July). Washington: International Monetary Fund.

Berner, Richard, Peter B. Clark, Jared Enzler, and Barbara Lowrey. 1974. International Sources of Domestic Inflation. International Finance Discussion Papers 55 (November). Washington: Board of Governors of the Federal Reserve System.

Berner, Richard, Peter B. Clark, Howard Howe, Sung Kwack, and Guy Stevens. 1975. Simultaneous Determination of the US Balance of Payments and Exchange Rates: An Exploratory Report. International Finance Discussion Papers 59 (February). Washington: Board of Governors of the Federal Reserve System.

Berner, Richard, Peter B. Clark, Howard Howe, Sung Kwack, and Guy Stevens. 1977. A Multi-Country Model of the International Influences on the US Economy: Preliminary Results. International Finance Discussion Papers 115 (December). Washington: Board of Governors of the Federal Reserve System.

BIS (Bank for International Settlements). 1998. Reports on the International Financial Architecture: Reports of Working Groups. Basel. Available at www.bis.org/publ/othp01.htm (accessed on June 30, 2014).

Bordo, Michael D., and Barry Eichengreen. 2013. Bretton Woods and the Great Inflation. In The Great Inflation: The Rebirth of Modern Central Banking, ed. Michael D. Bordo and Athanasios Orphanides. A National Bureau of Economic Research Conference Report. Chicago: University of Chicago Press.

Bordo, Michael D., Owen F. Humpage, and Anna J. Schwartz. Forthcoming. Strained Relations: US Monetary Policy and Foreign-Exchange Operations in the Twentieth Century. Chicago: University of Chicago Press.

Boughton, James M. 2001. Silent Revolution: The International Monetary Fund 1979-1989. Washington: International Monetary Fund.

Boughton, James M. 2012. Tearing Down Walls: The International Monetary Fund 1990-1999. Washington: International Monetary Fund.

Brayton, Flint, Andrew Levin, Ralph Tryon, and John C. Williams. 1997. The Evolution of Macro Models at the Federal Reserve Board. Washington: Board of Governors of the Federal Reserve System. Available at http://www.federalreserve.gov/PUBS/FEDS/1997/199729/199729pap.pdf (accessed on June 6, 2014).

Bryant, Ralph C. 2014 (forthcoming). Oral history. Washington: Board of Governors of the Federal Reserve System. Available when released at www.federalreserve.gov.

Bryant, Ralph C., Dale W. Henderson, Gerald Holtham, Peter Hooper, and Steven A. Symansky, ed. 1988. Empirical Macroeconomics for Interdependent Economies (two volumes). Washington: Brookings Institution.

Bryant, Ralph C., Gerald Holtham, and Peter Hooper, ed. 1988. External Deficits and the Dollar: The Pit and the Pendulum. Washington: Brookings Institution. 
Bryant, Ralph C., Peter Hooper, and Catherine L. Mann. 1993. Evaluating Policy Regimes: New Research in Empirical Macroeconomics. Washington: Brookings Institution.

Bryson, Jay H. 1993. Macroeconomic Stabilization through Monetary and Fiscal Policy Coordination: Implications for European Monetary Union. International Finance Discussion Papers 453 (September). Washington: Board of Governors of the Federal Reserve System.

Burns, Arthur F. 1978. The Anguish of Central Banking. Washington: Per Jacobsson Foundation.

Burns, Arthur F. 1985. Need for Order in International Finance. In Reflections of an Economic Policy Maker: Speeches and Congressional Statements: 1969-1978. Washington: American Enterprise Institute for Public Policy Research.

Clark, Peter B. 1974. The Effects of Recent Exchange Rates Changes on the US Trade Balance. International Finance Discussion Papers 52 (September). Washington: Board of Governors of the Federal Reserve System.

Cline, William C. 1983. International Debt and the Stability of the World Economy. Policy Analyses in International Economics 4 (September). Washington: Peterson Institute for International Economics.

Cline, William R. 1995. International Debt Reexamined. Washington: Peterson Institute for International Economics.

Cooper, Richard N., and Jane Sneddon Little. 2000. US Monetary Policy in an Integration World: 1960-2000. In The Evolution of Monetary Policy and the Federal Reserve System Over the Past Thirty Years: A Conference in Honor of Frank E. Morris, ed. Richard W. Kopcke and Lynn Elaine Browne. Conference Series 45. Boston: Federal Reserve Bank of Boston.

Cross, Sam Y. 1990. Treasury and Federal Reserve Foreign Exchange Operations: February-April 1990. Federal Reserve Bank of New York Quarterly Review 15, no. 1 (spring): 66-72.

Cross, Sam Y., and Edwin M. Truman. 1990. Task Force on System Foreign Currency Operations. Memorandum to the Federal Open Market Committee (March 9). Available from the FOMC Secretariat, Board of Governors of the Federal Reserve System. Washington.

Danker, Deborah, and Peter Hooper. 1990. International Financial Markets and the US External Imbalance. International Finance Discussion Papers 372 (January). Washington: Board of Governors of the Federal Reserve System.

Dooley, Michael P., William Helkie, Ralph Tryon, and John Underwood. 1983. An Analysis of External Debt Positions of Eight Developing Countries Through 1990. International Finance Discussion Papers 227 (August). Washington: Board of Governors of the Federal Reserve System.

Dooley, Michael P., and Jeffrey R. Shafer. 1976. Analysis of Short-Run Exchange Rate Behavior March 1973 to September 1975. International Finance Discussion Papers 76 (February). Washington: Board of Governors of the Federal Reserve System.

Edison, Hali J. 1988a. Evaluation of IF's Exchange Rate Forecasts 1979-1987. Memorandum to the Exchange Rate Forecasting Group (April 19). Photocopy.

Edison, Hali J. 1988b. Special Board Briefing on Exchange Rate Forecasting (May 23). Photocopy.

Edison, Hali J. 1990. Foreign Currency Operations: An Annotated Bibliography. International Finance Discussion Papers 380 (May). Washington: Board of Governors of the Federal Reserve System.

Edison, Hali J., and Linda S. Kole. 1994. European Monetary Arrangements: Implications for the Dollar, Exchange Rate Variability, and Credibility. International Finance Discussion Papers 468 (May). Washington: Board of Governors of the Federal Reserve System.

Eichengreen, Barry. 2013. Does the Federal Reserve Care about the Rest of the World? Journal of Economic Perspectives 27, no. 4 (fall): $87-104$.

Fisher, Peter R. 1994. Treasury and Federal Reserve Foreign Exchange Operations: July to September 1994. FRBNY Quarterly Review 19, no. 2 (summer): 1-10. 
Fisher, Peter, Donald Kohn, and Edwin Truman. 1996. Issues Related to Review of System's Swap Arrangements (March 14). Washington: Board of Governors, FOMC Service Center. Photocopy.

Fisher, Peter, and Edwin Truman. 1998. Update on the Federal Reserve Swap Network (September 28). Washington: Board of Governors, FOMC Service Center. Photocopy.

FRB (Board of Governors of the Federal Reserve System). 1971. Meeting of the Federal Open Market Committee: Minutes of Actions (March 9). Washington. Available at www.federalreserve.gov/monetarypolicy/files/fomcmoal9710309.pdf (accessed on June 9, 2014).

FRB (Board of Governors of the Federal Reserve System). 1973. Greenbook (December). Washington. Available at www.federalreserve.gov/monetarypolicy/files/FOMC19731218 19731212.pdf (accessed on June 9, 2014).

FRB (Board of Governors of the Federal Reserve System). 1976a. Record of Policy Actions of the Federal Open Market Committee: December 20-21, 1996. Washington. Available at www.federalreserve.gov/monetarypolicy/files/fomcropal9761221.pdf (accessed on June 11, 2014).

FRB (Board of Governors of the Federal Reserve System). 1976b. Transcript: December 20-21, 1996. Washington. Available at www.federalreserve.gov/monetarypolicy/files/FOMC19761221meeting.pdf (accessed on June 11, 2014).

FRB (Board of Governors of the Federal Reserve System). 1980. FOMC Presentation: International Financial Trends. Washington. Available at www.federalreserve.gov/monetarypolicy/files/FOMC19800205material.pdf (accessed on June 13, 2014).

FRB (Board of Governors of the Federal Reserve System). 1981. New Monetary Control Procedures. Federal Reserve Staff Study Volumes 1 and 11 . Washington.

FRB (Board of Governors of the Federal Reserve System). 1982. Presentation Materials, October 5, 1982. Washington. Available at www.federalreserve.gov/monetarypolicy/files/FOMC19821005material.pdf (accessed on July 4, 2014).

FRB (Board of Governors of the Federal Reserve System). 1983a. Presentation Materials, May 24, 1983. Washington. Available at http://www.federalreserve.gov/monetarypolicy/files/FOMC19830524material.pdf (accessed on August 12, 2014).

FRB (Board of Governors of the Federal Reserve System). 1983b. Record of Policy Actions, May 24, 1983. Washington. Available at http://www.federalreserve.gov/monetarypolicy/files/fomcropal9830524.pdf (accessed on June 28, 2014).

FRB (Board of Governors of the Federal Reserve System). 1984. The US External Position, May 21, 1984. Washington. Available at www.federalreserve.gov/monetarypolicy/files/FOMC19840522material.pdf (accessed on June 24, 2014).

FRB (Board of Governors of the Federal Reserve System). 1985a. Notes for FOMC Meeting, October 1, 1985. Washington. Available at www.federalreserve.gov/monetarypolicy/files/FOMC19851001material.pdf (accessed on June 24, 2014).

FRB (Board of Governors of the Federal Reserve System). 1985b. Presentation Materials, November 4-5, 1985. Washington. Available at http://www.federalreserve.gov/monetarypolicy/files/FOMC19851217material.pdf (accessed on July 27).

FRB (Board of Governors of the Federal Reserve System). 1985c. Transcript of Conference Call, January 18, 1985. Washington. Available at www.federalreserve.gov/monetarypolicy/files/FOMC19850118confcall.pdf (accessed on June 24, 2014).

FRB (Board of Governors of the Federal Reserve System). 1987. Presentation Materials: February 10-11, 1987. Washington. Available at www.federalreserve.gov/monetarypolicy/files/FOMC19870211material.pdf (accessed on June 25, 2014).

FRB (Board of Governors of the Federal Reserve System). 1988. Presentation Materials: February 9-10, 1988. Washington. Available at www.federalreserve.gov/monetarypolicy/files/FOMC19880210material.pdf (accessed on June 25, 2014).

FRB (Board of Governors of the Federal Reserve System). 1990a. Presentation Materials: August 21, 1990. Washington. Available at www.federalreserve.gov/monetarypolicy/files/FOMC19900821material.pdf (accessed on June 24, 2014).

FRB (Board of Governors of the Federal Reserve System). 1990b. Presentation Materials: March 27, 1990. Washington. Available at www.federalreserve.gov/monetarypolicy/files/FOMC19900327material.pdf (accessed on June 26, 2014). 
FRB (Board of Governors of the Federal Reserve System). 1990c. Record of Policy Actions: March 27, 1990. Washington. Available at www.federalreserve.gov/monetarypolicy/files/fomcropal9900327.pdf (accessed on June 25, 2014).

FRB (Board of Governors of the Federal Reserve System). 1990d. Transcript: March 27, 1990. Washington. Available at www.federalreserve.gov/monetarypolicy/files/FOMC19900327meeting.pdf (accessed on June 25, 2014).

FRB (Board of Governors of the Federal Reserve System). 1992a. Minutes, July 5-6, 1992. Washington. Available at www.federalreserve.gov/fomc/MINUTES/1994/19940706min.htm (accessed on June 29, 2014).

FRB (Board of Governors of the Federal Reserve System). 1992b. Presentation Materials, March 31, 1992. Washington. Available at www.federalreserve.gov/monetarypolicy/files/FOMC1992033lmaterial.pdf (accessed on June 29, 2014).

FRB (Board of Governors of the Federal Reserve System). 1994. Transcript: Conference Call July 20, 1994. Washington. Available at www.federalreserve.gov/monetarypolicy/files/FOMC19940720confcall.pdf (accessed on June 30, 2014).

FRB (Board of Governors of the Federal Reserve System). 1996a. Transcript: August 20, 1996. Washington. Available at www.federalreserve.gov/monetarypolicy/files/FOMC19960820meeting.pdf (accessed on June 30, 2014).

FRB (Board of Governors of the Federal Reserve System). 1996b. Transcript: July 2-3, 1996. Washington. Available at www.federalreserve.gov/monetarypolicy/files/FOMC19960703meeting.pdf (accessed on June 30, 2014).

FRB (Board of Governors of the Federal Reserve System). 1997. Greenbook (November). Available at http://www.federalreserve.gov/monetarypolicy/files/fomc19971216gbpt119971211.pdf (accessed on August 5, 2014).

FRB (Board of Governors of the Federal Reserve System). 1998a. Greenbook (November). Available at http://www.federalreserve.gov/monetarypolicy/files/fomc19981117gbpt119981112.pdf (accessed August 5, 2014). FRB (Board of Governors of the Federal Reserve System). 1998b. Minutes: November 17, 1998. Washington. Available at www.federalreserve.gov/fomc/minutes/19981117.htm (accessed on June 30, 2014).

FRB (Board of Governors of the Federal Reserve System). 1999a. Greenbook (November). Available at http://www.federalreserve.gov/monetarypolicy/files/fomc19991116gbpt119991110.pdf (accessed August 5, 2014).

FRB (Board of Governors of the Federal Reserve System). 1999b. Guide to the Interagency Country Exposure Review Committee Process. Washington. Available at www.federalreserve.gov/boarddocs/SRLETTERS/1999/sr9935al.pdf (accessed on June 13, 2014).

FRB (Board of Governors of the Federal Reserve System). 2000. Transcript: October 3. Washington, Available at http://www.federalreserve.gov/monetarypolicy/files/FOMC20001003meeting.pdf (accessed on October 28, 2014).

Freund, Caroline L. 2000. Current Account Adjustment in Industrial Countries. International Finance Discussion Papers 692 (December). Washington: Board of Governors of the Federal Reserve System.

G-6 (Group of Six). 1987. Statement of the G6 Finance Ministers and Central Bank Governors (Louvre Accord). Paris. Available at http://www.g8.utoronto.ca/finance/fm870222.htm (accessed on July 17, 2014).

G-7 (Group of Seven). 1997. G-7 Statement on the Korean Situation (December 24). Available at http://www.g8.utoronto.ca/finance/fin dec2497.htm (accessed on July 24, 2014).

G-10 (Group of Ten). 1996. The Resolution of Sovereign Liquidity Crises: A Report to the Ministers and Governors Prepared under the Auspices of the Deputies. Basel: Bank for International Settlements.

Gagnon, Joseph E., Paul Masson, and Warwick J. McKibbin. 1996. German Unification: What Have We Learned from MultiCountry Models? International Finance Discussion Papers 547 (April). Washington: Board of Governors of the Federal Reserve System.

Gray, Jo Anna, and Jeffrey R. Shafer. 1981. The Implications of a Floating Exchange Rate Regime: A Survey of Federal Reserve System Papers. International Finance Discussion Papers 173 (January). Washington: Board of Governors of the Federal Reserve System. 
Greene, Margaret L. 1984a. US Experience with Exchange Market Intervention: January-March 1975. Staff Studies 127. Washington: Board of Governors of the Federal Reserve System.

Greene, Margaret L. 1984b. US Experience with Exchange Market Intervention: October 1980-September 1981. Staff Studies 129. Washington: Board of Governors of the Federal Reserve System.

Greene, Margaret L. 1984c. US Experience with Exchange Market Intervention: September 1977-December 1979. Staff Studies 128. Washington: Board of Governors of the Federal Reserve System.

Greenspan, Alan. 1998. Is there a New Economy? Remarks at the Haas Annual Business Faculty Research Dialogue (September 4). Berkeley. Available at http://fraser.stlouisfed.org/docs/historical/greenspan/Greenspan 19980904.pdf (accessed on June 26, 2014).

Greenspan, Alan. 2007. The Age of Turbulence: Adventures in a New World. New York: Penguin Press.

Helkie, William L., and Peter Hooper. 1987. The US External Deficit in the 1980's: An Empirical Analysis. International Finance Discussion Papers 304 (February). Washington: Board of Governors of the Federal Reserve System.

Helkie, William L., and Peter Hooper. 1989. US External Adjustment: Progress and Prospects. International Finance Discussion Papers 345 (March). Washington: Board of Governors of the Federal Reserve System.

Henderson, Dale W., and Stephanie Sampson. 1983. Intervention in Foreign Exchange Markets: A Summary of Ten Staff Studies. Federal Reserve Bulletin 69, no. 11 (November): 830-36.

Henning, C. Randall. 1994. Currencies and Politics in the United States, Germany, and Japan. Washington: Peterson Institute for International Economics.

Henning, C. Randall. 1999. The Exchange Stabilization Fund: Slush Money or War Chest? Policy Analyses in International Economics no. 57. Washington: Peterson Institute for International Economics.

Hooper, Peter, Karen Johnson, Donald L. Kohn, David E. Lindsey, Richard D. Porter, and Ralph W. Tyron, ed. 1990. Monetary Aggregates and Financial Sector Behavior in Interdependent Economies. Washington: Board of Governors of the Federal Reserve System.

Hooper, Peter, Karen Johnson, and Jaime Marquez. 1998. Trade Elasticities for G-7 Countries. International Finance Discussion Papers 609 (April). Washington: Board of Governors of the Federal Reserve System.

Hooper, Peter, and Barbara Lowery. 1979. Impact of Dollar Depreciation on the US Price Level: An Analytical Survey of Empirical Estimates. International Finance Discussion Papers 128 (January). Washington: Board of Governors of the Federal Reserve System.

Hooper, Peter, and Catherine L. Mann. 1987. The US External Deficit: Its Causes and Persistence. International Finance Discussion Papers 316 (November). Washington: Board of Governors of the Federal Reserve System.

Hooper, Peter, Karen Johnson, and Jaime Marquez. 1998. Trade Elasticities for G-7 Countries. International Finance Discussion Papers 609 (April). Washington: Board of Governors of the Federal Reserve System.

Hooper, Peter, and John Morton. 1978a. Index of the Weighted-Average Exchange Value of the US Dollar: Revision. Federal Reserve Bulletin 64 (August): 700.

Hooper, Peter, and John Morton. 1978b. Summary Measures of the Dollar's Foreign Exchange Value. Federal Reserve Bulletin 64 (October): 783-89.

Hooper, Peter, and John Morton. 1980. Fluctuations in the Dollar: A Model of Nominal and Real Exchange Rate Determination. International Finance Discussion Papers 169 (October). Washington: Board of Governors of the Federal Reserve System.

Houthakker, Hendrik S., and Stephen P. Magee. 1969. Income and Price Elasticities in World Trade. Review of Economics and Statistics 51: 111-25. 
Howard, David H. 1989. The United States as A Heavily Indebted Country. International Finance Discussion Papers 353 (May). Washington: Board of Governors of the Federal Reserve System.

IMF (International Monetary Fund). 2014. The Fund's Lending Framework and Sovereign Debt_Preliminary Considerations (May). Washington.

Isard, Peter. 1977. The Process of Exchange Rate Determination: A Survey of Popular Views and Recent Models. International Finance Discussion Papers 101 (September). Washington: Board of Governors of the Federal Reserve System. Johnson, Karen H. 1994. International Dimension of European Monetary Union: Implications for the Dollar. International Finance Discussion Papers 469 (May). Washington: Board of Governors of the Federal Reserve System.

Johnson, Karen H. 2014 (forthcoming). Oral history. Washington: Board of Governors of the Federal Reserve System. Available when released at $\underline{w w w . f e d e r a l r e s e r v e . g o v}$.

Junz, Helen B. 1973. Balance of Payments Aims and Structures in the 1970s. International Finance Discussion Papers 38 (December). Washington: Board of Governors of the Federal Reserve System.

Jurgensen, Philippe. 1983. Report of the Working Group on Exchange Market Intervention. Washington: US Department of the Treasury. March. Photocopy.

Kamin, Steven B. 1996. Real Exchange Rates and Inflation in Exchange-Rate Based Stabilizations: An Empirical Examination. International Finance Discussion Papers 554 (June). Washington: Board of Governors of the Federal Reserve System. Kamin, Steven B., and John H. Rogers. 1996. Monetary Policy in the End-Game to Exchange-Rate Based Stabilizations: The Case of Mexico. International Finance Discussion Papers 540 (February). Washington: Board of Governors of the Federal Reserve System.

Kamin, Steven B., and John H. Rogers. 1997. Output and the Real Exchange Rates in Developing Countries: An Application to Mexico. International Finance Discussion Papers 580 (May). Washington: Board of Governors of the Federal Reserve System.

Katz, Samuel 1. 1973. 'Imported Inflation' and the Balance of Payments. International Finance Discussion Papers 115 (December). Washington: Board of Governors of the Federal Reserve System.

Kwack, Sung Y. 1973. The Effect of Foreign Inflation on Domestic Prices and the Relative Price Advantage of Exchange Rate Changes. International Finance Discussion Papers 35 (November). Washington: Board of Governors of the Federal Reserve System.

Lane, Philip R., and Gian Maria Milesi-Ferretti. 2007. The External Wealth of Nations Mark 1l: Revised and Extended Estimates of Foreign Assets and Liabilities, 1970-2004. Journal of International Economics 73 (November): $223-50$.

Leahy, Michael P. 1998. New Summary Measures of the Foreign Exchange Value of the Dollar. Federal Reserve Bulletin 84 (October): 811-18.

Loretan, Mico. 2005. Indexes of the Foreign Exchange Value of the Dollar. Federal Reserve Bulletin 91 (winter): 1-8. Lubitz, Raymond. 1978. The Italian Economic Crises of the 1970s. International Finance Discussion Papers 120 (June). Washington: Board of Governors of the Federal Reserve System.

Mann, Catherine L. 1999. Is the US Trade Deficit Sustainable? Washington: Peterson Institute for International Economics. Meltzer, Allan H. 2009. A History of the Federal Reserve. Volume 2, Book 2, 1970-1986. Chicago: University of Chicago Press.

Meltzer, Allan H. 2013. Comment on Bordo and Eichengreen. In The Great Inflation: The Rebirth of Modern Central Banking, ed. Michael D. Bordo and Athanasios Orphanides. A National Bureau of Economic Research Conference Report. Chicago: University of Chicago Press.

Meese, Richard, and Kenneth Rogoff. 1981. Empirical Exchange Rate Models of the Seventies: Are Any Fit to Survive? International Finance Discussion Papers 184 (June). Washington: Board of Governors of the Federal Reserve System. 
Meese, Richard, and Kenneth Rogoff. 1982. The Out-of-Sample Failure of Exchange Rate Models: Sampling Error or Misspecification? International Finance Discussion Papers 204 (March). Washington: Board of Governors of the Federal Reserve System.

Meese, Richard, and Kenneth Rogoff. 1983. Empirical Exchange Rate Models of the Seventies: Do They Fit Out-of-Sample? Journal of International Economics 14 (February): 3-24.

Pardee, Scott E. 1981. Notes for FOMC Meeting, May 18, 1981. Washington: Board of Governors of the Federal Reserve System. Available at www.federalreserve.gov/monetarypolicy/files/FOMC19810331material.pdf (accessed on June 24, 2014).

Pauls, B. Dianne. 1987. Measuring the Foreign Exchange Value of the Dollar. Federal Reserve Bulletin 73 (June): 411-22.

Pauls, B. Dianne. 1990. U.S. Exchange Rate Policy: Bretton Woods to Present. Federal Reserve Bulletin 76 (November): $891-$ 908.

Schenk, Catherine. 2010. The Decline of Sterling: Managing the Retreat of an International Currency 1945-1992. Cambridge, UK: Cambridge University Press.

Sheets, Nathan. 1995. Capital Flight from the Countries in Transition: Some Theory and Empirical Evidence. International Finance Discussion Papers 514 (July). Washington: Board of Governors of the Federal Reserve System.

Sheets, Nathan, and Simona Boata. 1996. Eastern European Export Performance during the Transition. International Finance Discussion Papers 562 (September). Washington: Board of Governors of the Federal Reserve System.

Siegman, Charles J. 1994. The Bank for International Settlements and the Federal Reserve. Federal Reserve Bulletin 80, no. 10 (October): 900-906.

Silber, William L. 2012. Volcker: The Triumph of Persistence. New York: Bloomsbury Press.

Solomon, Robert. 1977. The International Monetary System 1945-1981: An Insider's View. New York: Harper and Row.

Solomon, Robert. 2014 (forthcoming). Oral history. Washington: Board of Governors of the Federal Reserve System.

Available when released at www.federalreserve.gov.

Stekler, Lois E., and William L. Helkie. 1989. Implications for Future US Net International Investment Position of Growing US Net International Indebtedness. International Finance Discussion Papers 358 (July). Washington: Board of Governors of the Federal Reserve System.

Stevens, Guy, Richard Berner, Peter B. Clark, Ernesto Hernandez-Cata, Howard Howe, and Sung Kwack. 1984. The U.S. Economy in an Interdependent World: A Multicountry Model. Washington: Board of Governors of the Federal Reserve System.

Summit Finance Ministers, Central Bank Governors, and Representatives of the European Community. 1983. Statement on the Intervention Study, April 29.

Truman, Edwin M. 1982. International Economic and Financial Conditions. Available at http://www.federalreserve.gov/monetarypolicy/files/FOMC19821116material.pdf (accessed on June 15, 2014).

Truman, Edwin M. 2003a. Inflation Targeting in the World Economy. Washington: Peterson Institute for International Economics.

Truman, Edwin M. 2003b. The Limits of Exchange Market Intervention. In Dollar Overvaluation and the World Economy, ed. C. Fred Bergsten and John Williamson. Washington: Peterson Institute for International Economics.

Truman, Edwin M. 2004. A Critical Review of Coordination Efforts in the Past. In Macroeconomic Policies in the World Economy, ed. Horst Siebert. Berlin: Springer Verlag.

Truman, Edwin M. 2005. Reflections [Monetary Policy 25 Years after October 1979]. Federal Reserve Bank of St. Louis Review 87 (March/April, part 2): 353-57.

Truman, Edwin M. 2006. What Can Exchange Rates Tell Us? In C. Fred Bergsten and the World Economy, ed. Michael Mussa. Washington: Peterson Institute for International Economics. 
Truman, Edwin M. 2012. John Williamson and the Evolution of the International Monetary System. PIIE Working Paper 12-13 (August). Washington: Peterson Institute for International Economics.

Truman, Edwin M. 2014 (forthcoming). Oral history. Washington: Board of Governors of the Federal Reserve System. Available when released at www.federalreserve.gov.

Truman, Edwin M., and others. 1981. The New Federal Reserve Operating Procedures: An External Perspective. In New Monetary Control Procedures. Federal Reserve Staff Study Volumes 1 and II. Washington: Board of Governors of the Federal Reserve System.

US Treasury. 2014. U.S.-China Joint Fact Sheet: Sixth Meeting of the Strategic and Economic Dialogue. Washington. Available at www.treasury.gov/press-center/press-releases/Pages/jl2561.aspx (accessed on July 24, 2014).

Volcker, Paul A. 1980. The Recycling Problem Revisited. Remarks before the Graduate School of Business Administration, New York University (March 1). New York. Available at

http://fraser.stlouisfed.org/docs/historical/volcker/Volcker 19800301.pdf (accessed on June 13, 2104).

Volcker, Paul A, and Toyoo Gyohten. 1992. Changing Fortunes: The World's Money and the Threat to American Leadership. New York: Times Books.

Warnock, Francis E., and Molly Mason. 2000. The Geography of Capital Flows: What We Can Learn from Benchmark Surveys of Foreign Equity Holdings. International Finance Discussion Papers 688 (December, latest version April 2001). Washington: Board of Governors of the Federal Reserve System.

Woodward, Bob. 2000. Maestro: Greenspan's Fed and the American Boom. New York: Simon and Schuster. 


\begin{tabular}{|c|c|c|c|c|c|c|c|c|}
\hline \multicolumn{9}{|c|}{$\begin{array}{l}\text { Table } 1 \text { Classification of international finance discussion papers: number of papers } \\
\text { (in parentheses) and percent of total papers, 1971-2000 }\end{array}$} \\
\hline Decade(s) & Inflation & $\begin{array}{l}\text { External } \\
\text { accounts }\end{array}$ & $\begin{array}{l}\text { US dollar } \\
\text { and } \\
\text { policy }\end{array}$ & $\begin{array}{c}\text { Financial } \\
\text { crises }\end{array}$ & Modeling & Countries & Other & $\begin{array}{c}\text { Total } \\
\text { papers }\end{array}$ \\
\hline $1970 s$ & (7) 4 & (28) 16 & (26) 15 & (5) 3 & (18) 11 & (11) 6 & (76) 44 & 171 \\
\hline $1980 \mathrm{~s}$ & (3) 1 & (29) 13 & (39) 18 & (17) 8 & (10) 4 & (30) 14 & (94) 42 & 222 \\
\hline 1990s & (10) 3 & (28) 9 & (40) 13 & (43) 14 & (4) 1 & (41) 14 & $\begin{array}{r}(136) \\
45\end{array}$ & 302 \\
\hline $\begin{array}{c}1971 \text { to } \\
2000\end{array}$ & (20) 3 & (85) 12 & $\begin{array}{r}(105) \\
15\end{array}$ & (65) 9 & (32) 5 & (82) 12 & $\begin{array}{r}(306) \\
44\end{array}$ & 695 \\
\hline \multicolumn{9}{|c|}{$\begin{array}{l}\text { Note: Percentages may not add to } 100 \text { because of rounding. } \\
\text { Sources: Board of Governors of the Federal Reserve System, www.federalreserve.gov/pubs/ifdp/2014/default.htm, and author's } \\
\text { classification. }\end{array}$} \\
\hline
\end{tabular}


Figure 1 US exports and imports of goods and services and external balances, 1970-2013
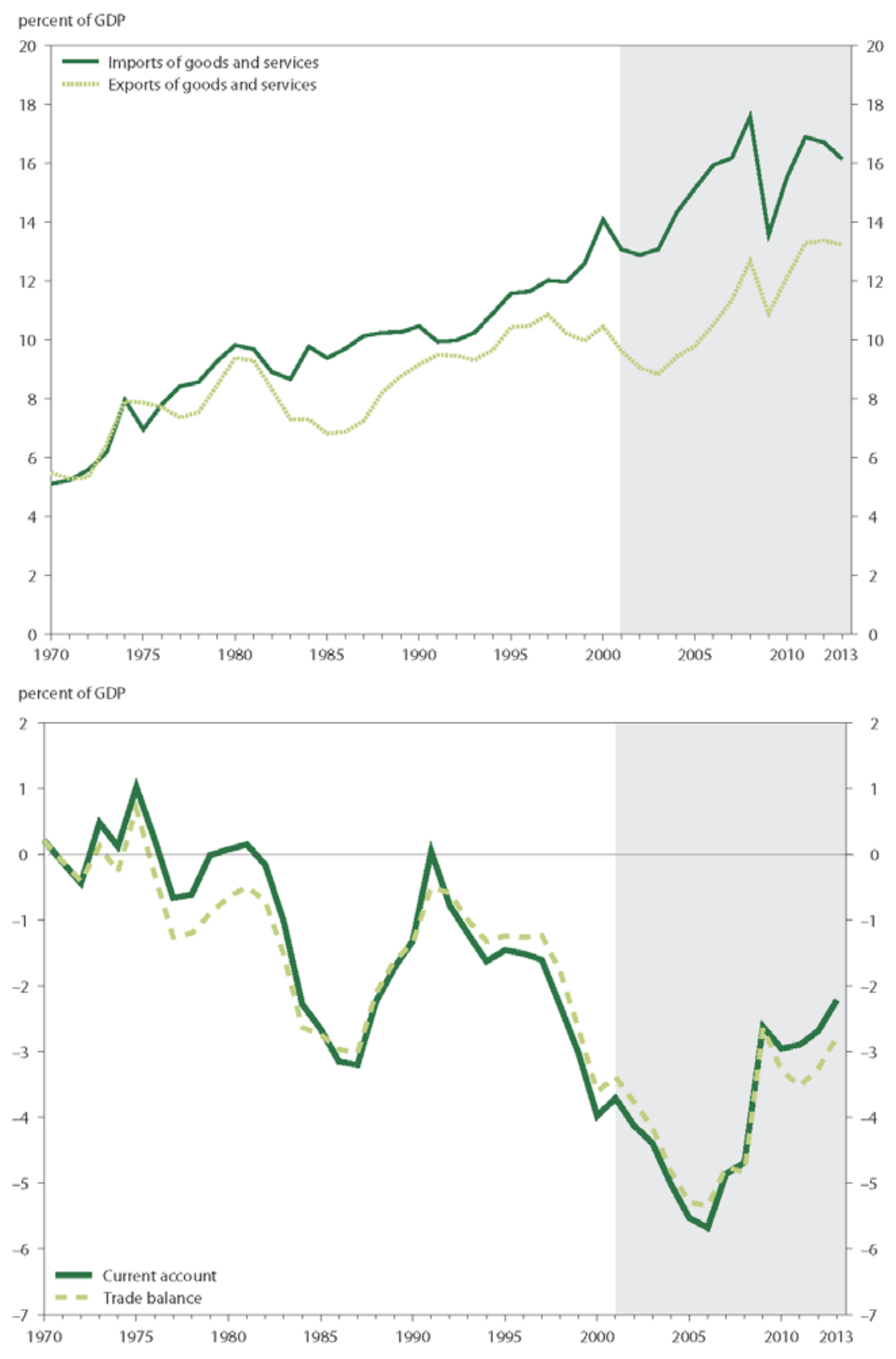

Source: Bureau of Economic Analysis, US Commerce Department 
Figure 2 US assets abroad and foreign assets in the United States, 1970-2013

percent of GDP

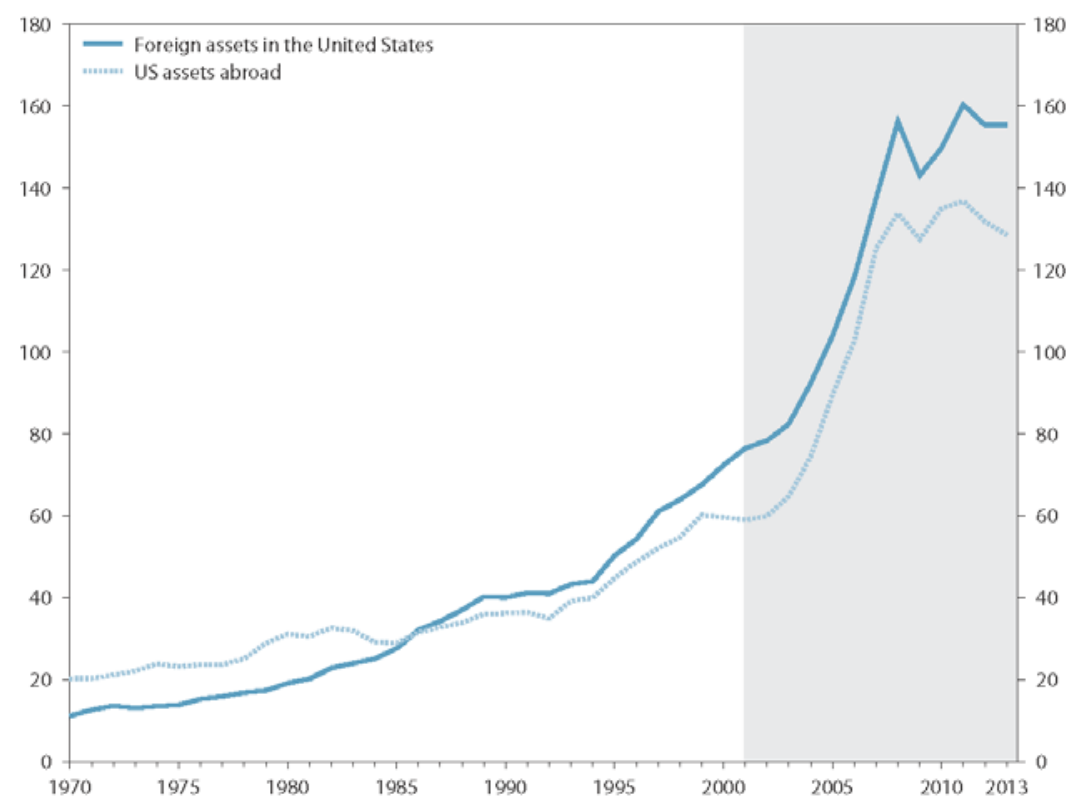

percent of GDP

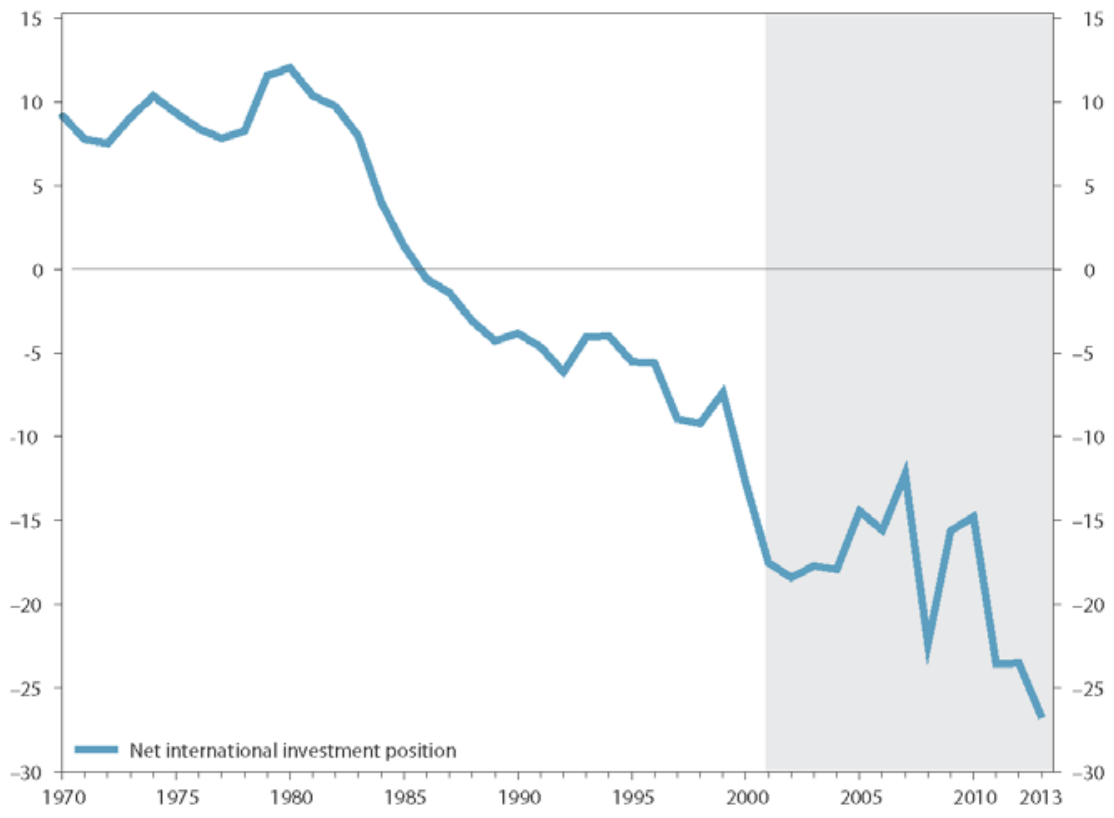

Sources: Bureau of Economic Analysis, US Commerce Department; updated and extended dataset by Lane and Milest-Ferretti, 2007; and author's calculations. 
Figure 3 US current account balance and price-adjusted foreign exchange value of the US dollar, 1970-2013

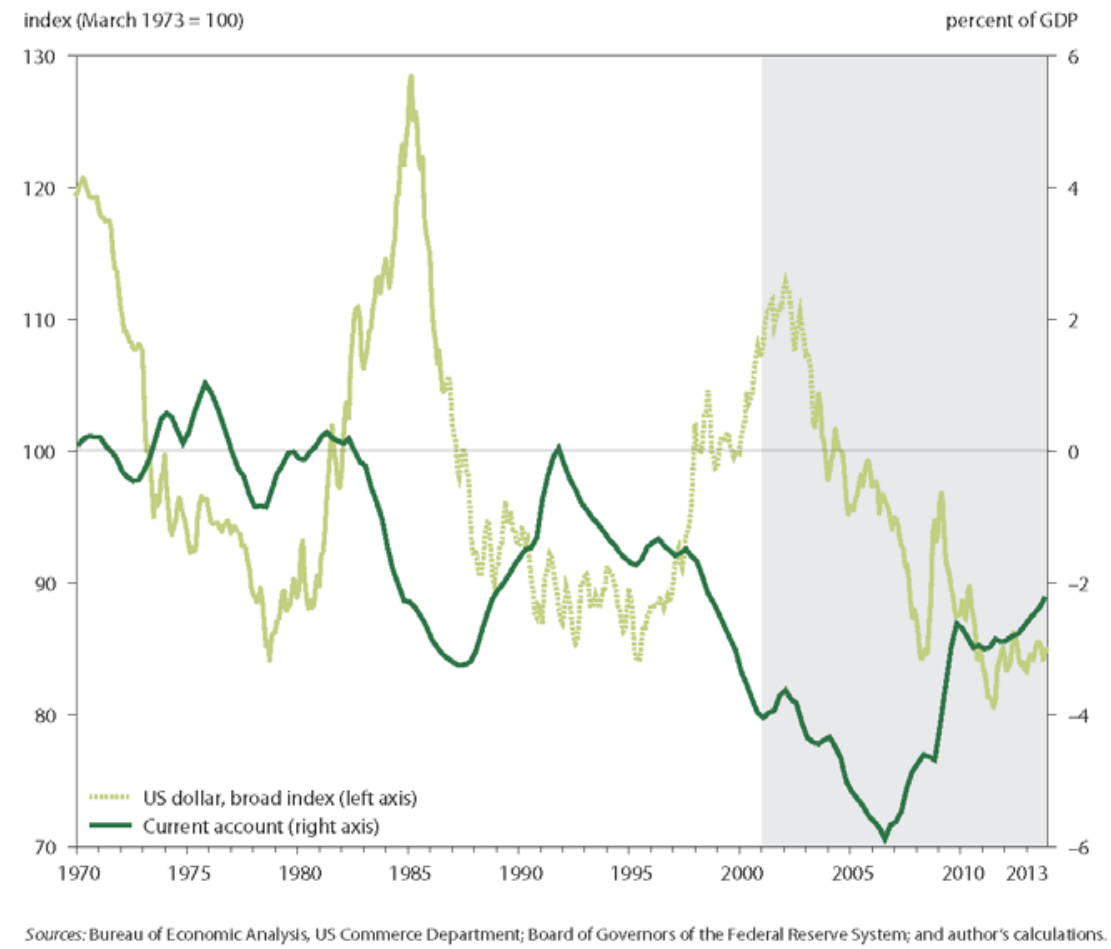


Figure 4 US real federal funds rate and 10-year treasury rate and the CPI inflation rate, 1970-1982 percentage points

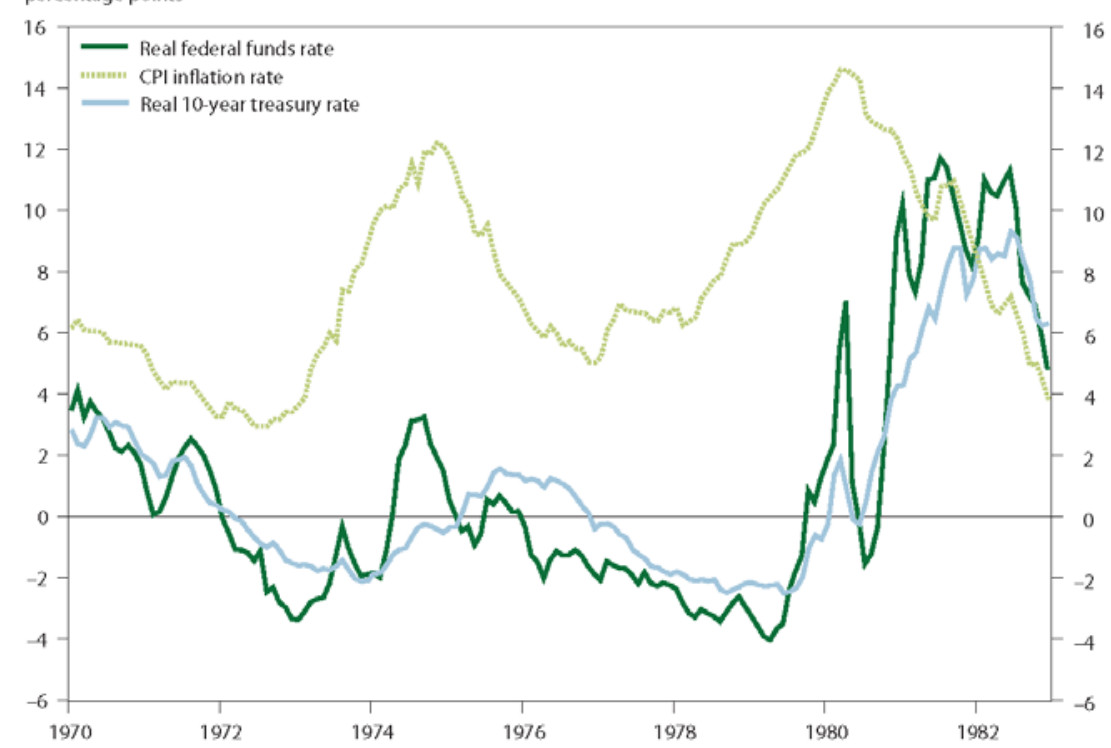

$\mathrm{CPI}=$ consumer price index

Sources: Board of Governors of the Federal Reserve System, US Bureau of Labor Statistics; and author's calculations. 
Figure 5 US real federal funds rate and 10-year treasury rate versus CPI inflation rate, 1980-1992 percentage points

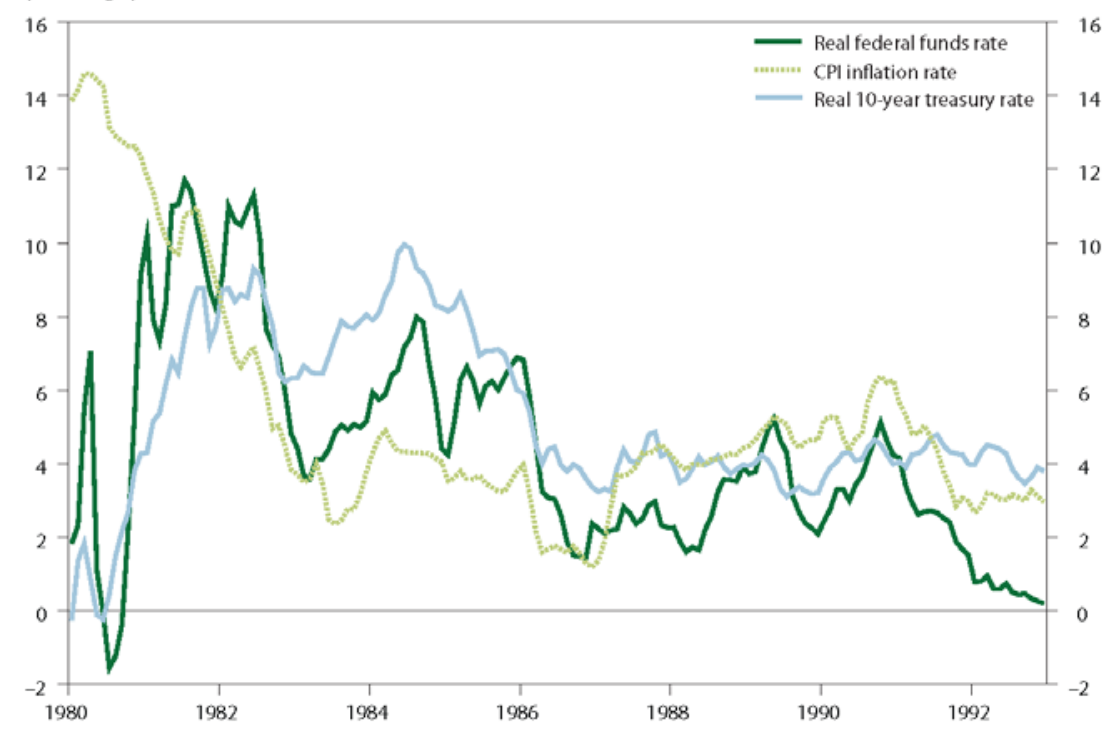

$\mathrm{CP1}=$ consumer price index

Sources: Board of Governors of the Federal Reserve System, US Bureau of Labor Statistic; and author's calculations. 
Figure 6 Indices of the price-adjusted foreign exchange value of the US dollar, 1973-2013 index (March 1973 $=100$ )

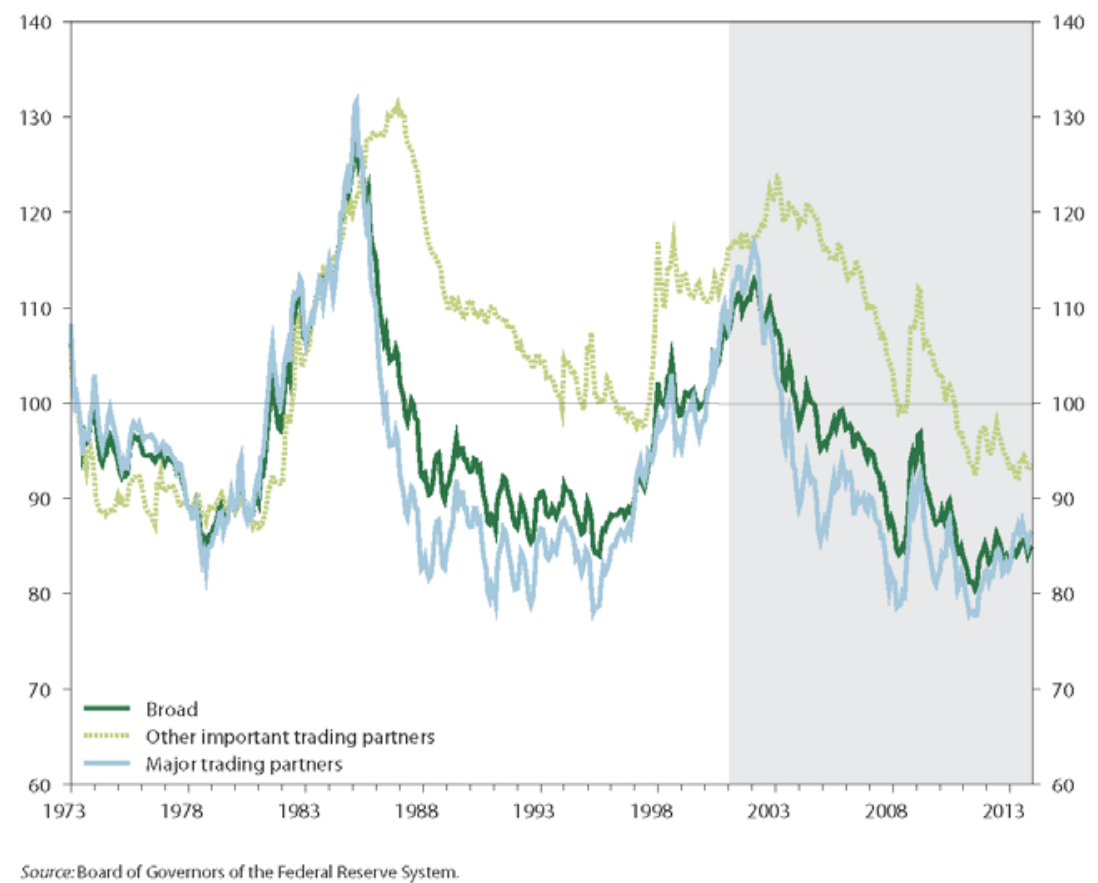


Figure 7 US real federal funds rate and 10-year treasury rate versus CPI inflation rate, 1990-2002 percentage points

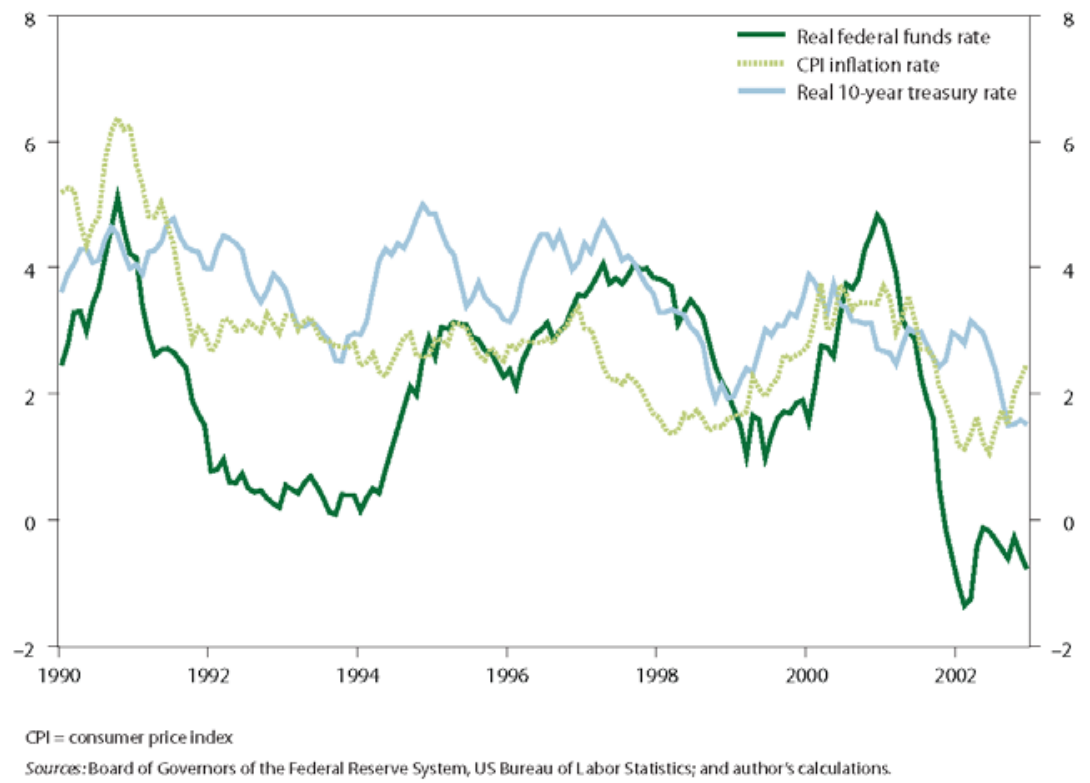

